Vol.15, No. 56, July, 2020, 845-870

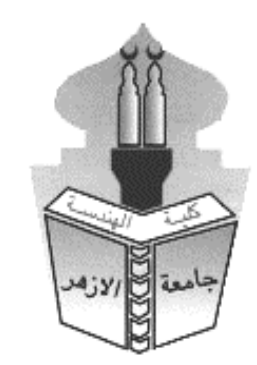

\title{
TOWARDS EFFECTIVE DESIGN GUIDELINES OF PILGRIMS' HOUSING IN MINA AT MAKKAH CITY
}

\author{
Amr Mohamed Zin Eldin El Zawahry \\ Researcher at Housing and Building National Research Center, Architecture and \\ Housing Research Institute, Egypt, Giza,.Egypt \\ E-mail: Amr_zaineldin@hotmail.com
}

\begin{abstract}
The utilized area of Mina is limited to the flat valley which is almost half of the legitimate area. In the same time, this developed area has a very low accommodation capacity (which is about one million pilgrims), Taking into account that the number of pilgrims reached 3 million pilgrims in $1430 \mathrm{AH}$. Increasing Mina's accommodation capacity is one of the most challenging issues because of the limited developable area. Any increase in the number of pilgrims will require an increase in the accommodation capacity and building density.

Therefore, this Research is interested in developing comprehensive integrated alternatives to help in increasing effectiveness of Mina's existing accommodation and formulate design guidelines to improve the design and increase the capacity of future development project for Mina's area. To achieve its objectives, the research utilized unpublished survey conducted by the Institute of the Custodian of the Two Holy Mosques for Hajj and Umrah Research as part of post occupancy evaluation of newly developed high capacity pilot project ( pilgrims' Housing Buildings) on the northern slopes of Mina mountains. It was conducted during the soft opening of this pilot project in1429- 1430 pilgrimage season. The survey covered planning, design and operation parameters. It was based on the users' satisfaction, operators' interviews, and evaluation checklist. Based on this survey, positives and negatives of design and operation issues were identified.

The research concluded with a set of design guidelines that can achieve pilgrims satisfaction and improve site arrangement, building design and management were formulated. Consequently, design modifications were established to develop existing buildings; and increase their effectiveness and capacity. Moreover, the research introduced an illustrative summary of the recommendations, guidelines and associated rates.
\end{abstract}

\section{KEY WORDS: Pilgrims' Housing, High Capacity Pilot Project, Mountain Slopes, Pilgrims' Satisfaction, Design Guidelines, Post Occupancy Evaluation, Mina Area, Makkah, Hajj, Umrah .}

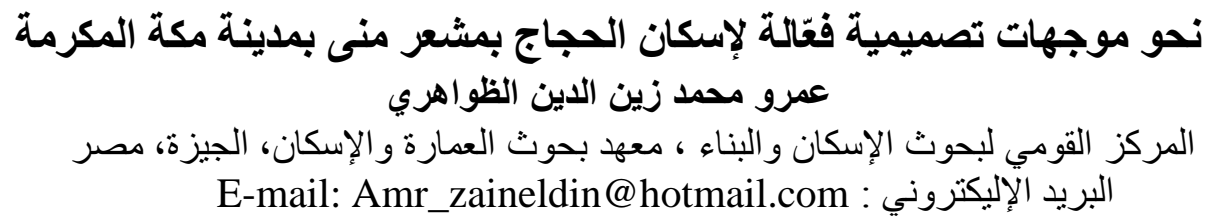




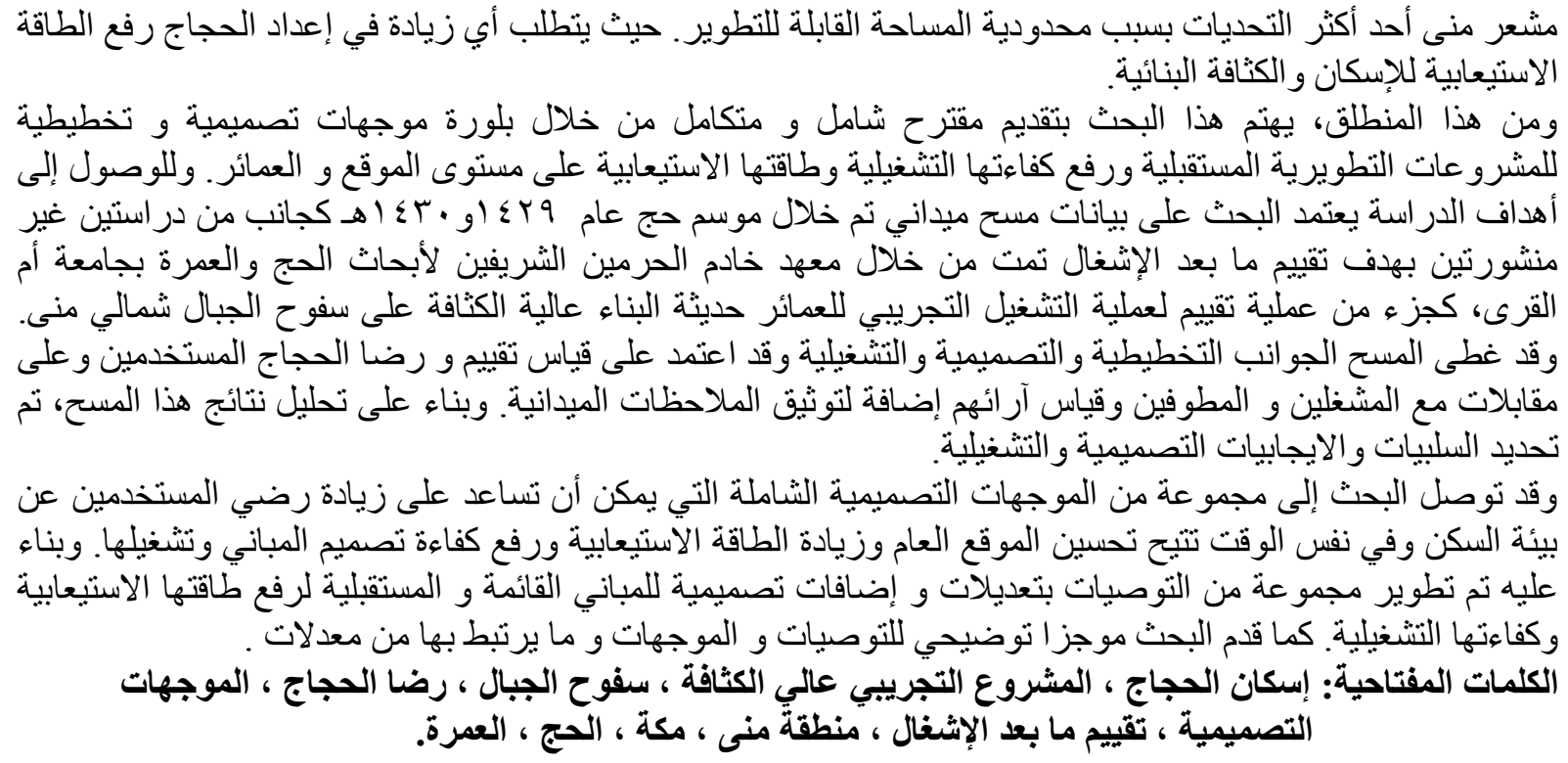

\section{POST OCCUPANCY EVALUATION (P.O.E)}

The study of the Pilgrimage Housing in Mina is considered one of the P.O.E studies, which is one of the commonly used terms such as the activity of Building Performance Evaluation (Prieser and Vischer, 2004). The emergence of the P.O.E was linked to the increasing attention given during the sixties to the relation between the Human Behavior, the Built Environment, Architectural and Urban Design and Planning and the emergence of many researches and studies related to the Environmental Design through the Ecological Psychology, Environmental Psychology, Environmental Sociology, Urban Sociology and Human Ecology, which tackled the study of the interaction and relation between the human and his/her behavior with the parts of the architectural system and the built environment from the level of the building to the different urban levels; as well as the emergence of research institutions specialized in the environment design including specialists in different fields (architectural, urban, planners, interior environment designers, psychologists, sociologists, human geographers, institution managers...) (Prieser 1988, 2015) (Amr El Zawahry, 2000). P.O.E evolved to fill the gap in the conventional building process, which consists of planning, programming, design, construction, and occupancy of a building. It represents the vital diagnostic step that is needed to feed the prescriptive tools of planning and programming (Voordt. and Wegen, 2005). It contributes to the continuous improvement of the planning process by identifying the positive and negative characteristics of the building and integrating such information in the future planning and design process and it focuses on the interaction of users with the building after the expiration of sufficient time (QDHPW ,2013).Hence, P.O.E is about procedures for determining whether or not design decisions made by the architect are delivering the performance needed by those who use the building (occupants). By using occupants as a benchmark in evaluation, P.O.E provides enormous potential for improving the performance of a building. (Voordt and Wegen, 2005). The gap between the actual performance of buildings and explicitly stated performance criteria (designingly determined) constitute the evaluation (Preiser et al, 1988). Also, One of the applications of POE is the comparison between the use that the designer intended for an environment and that to which its users put it. (Watson, C., 2003).It enables users to discuss issues of construction and usage and thus prepare a systematic assessment of their views, conclude their perceptions and link them to the level of housing and the built environment. Therefore, P.O.E is a base that contributes to creating buildings of high quality and more efficient and responsive for future users (Prieser, 1988, 2015).

Facility assessment is an automated process by users, for example, occupants of hotel rooms judge the efficiency of temperature, lighting, finishes, spaces and storage and its suitability with the rooms, and the sound insulation efficiency when listening to what is going on outside or in adjacent rooms. The aesthetic aspects of the rooms, the different spaces of the building 
and the views and external spaces are also evaluated, in addition to the functional evaluation of the interior spaces of the building, services and operation such as the elevators and the waiting time ( Prieser , 1988 ,2015). This process is applied on all building types (residential, educational, and administrative and health buildings ...).

2.1 Main Elements of the P.O.E Building Performance Evaluation (Building

Performance Elements): (Table 1)

\begin{tabular}{|c|c|c|}
\hline \multicolumn{3}{|c|}{ Table (1) (Prieser 1988, 2015) } \\
\hline Behavioral Elements & Functional Elements & Technical Elements \\
\hline $\begin{array}{l}\text { It deals with the social, psychological and } \\
\text { emotional sides of the users and their } \\
\text { relations with the social interactions } \\
\text { (privacy, symbolism, personal security, } \\
\text { personal space, communication, congestion, } \\
\text { distance of interaction, spatial } \\
\text { organizations...(Amr El Zawahry, 2000)) } \\
\text { all aimed at the user satisfaction and } \\
\text { general wellbeing. }\end{array}$ & $\begin{array}{l}\text { It deals with the } \\
\text { suitability of building } \\
\text { elements for users' } \\
\text { activities, usage } \\
\text { efficiency and its inter- } \\
\text { functional relations. }\end{array}$ & $\begin{array}{l}\text { It includes the technical } \\
\text { aspects and the attainment } \\
\text { of quality and effectiveness } \\
\text { of the security and safety } \\
\text { aspects, such as } \\
\text { firefighting, waste disposal, } \\
\text { sound, heat and lighting... }\end{array}$ \\
\hline
\end{tabular}

2.2 Types, trends, fields and methods of data collection and analysis for the P.O.E research and the applied ones in research: (Table 2)

\begin{tabular}{|c|c|c|c|}
\hline \multicolumn{4}{|c|}{ Table (2)(P.O.E References mentioned in the Research) (The researcher) } \\
\hline \multirow[t]{3}{*}{$\begin{array}{l}\text { Research } \\
\text { types }\end{array}$} & $\begin{array}{l}\text { Survey (from multiple sources } \\
\text { to provide information for } \\
\text { design considerations) }\end{array}$ & \multirow[t]{4}{*}{$\begin{array}{l}\text { Research } \\
\text { trends }\end{array}$} & $\begin{array}{l}\text { Diagnostic (identification of } \\
\text { variables necessary for the study to } \\
\text { identify problems and interactions) }\end{array}$ \\
\hline & $\begin{array}{l}\text { Case Study (Building or } \\
\text { Residential or Urban Area) }\end{array}$ & & $\begin{array}{l}\text { Descriptive (coexistence and } \\
\text { accurate description) }\end{array}$ \\
\hline & $\begin{array}{l}\text { Experimental study } \\
\text { (comparison before and after } \\
\text { adjustment) }\end{array}$ & & Theoretical (Hypothetical study) \\
\hline \multirow[t]{4}{*}{$\begin{array}{l}\text { Fields of } \\
\text { evaluation }\end{array}$} & Functional & & $\begin{array}{l}\text { Practical (making an adjustment and } \\
\text { studying its impact) }\end{array}$ \\
\hline & Technical, Environmental & \multirow{6}{*}{$\begin{array}{l}\text { Information } \\
\text { gathering } \\
\text { methods and } \\
\text { evaluation tools }\end{array}$} & Observing physical amendments \\
\hline & $\begin{array}{l}\text { Behavioral (social, cultural, } \\
\text { psychological) - the impact of } \\
\text { place on individuals and } \\
\text { groups }\end{array}$ & & $\begin{array}{l}\text { Observing environmental behaviors } \\
\text { (use and activities) }\end{array}$ \\
\hline & Economic & & \\
\hline \multirow{3}{*}{$\begin{array}{l}\text { Information } \\
\text { analysis } \\
\text { methods }\end{array}$} & \multirow{2}{*}{$\begin{array}{l}\text { Quantitative (figures, } \\
\text { percentages and statistics) }\end{array}$} & & Plans, maps and information \\
\hline & & & $\begin{array}{l}\text { Personal interviews (assessment and } \\
\text { satisfaction of users and officials) }\end{array}$ \\
\hline & Qualitative (usage patterns) & & $\begin{array}{l}\text { Questionnaire (user evaluation and } \\
\text { satisfaction) }\end{array}$ \\
\hline$*$ & d in the Study & & \\
\hline
\end{tabular}

\section{Description of Mina's Urban Environment:}

Mina is $6 \mathrm{~km}$ away from Makkah City Center and. It has a total area of $8.12 \mathrm{~km}^{2}$ and the flat area of which occupies $52 \%$, and the remaining area constitutes the steep mountains that are located north and south of the Mina Valley. The levels of the area of the valley range from 270 meters to 320 meters above sea level, while parts of the mountains reach 1000 meters above sea level. The Mina Valley is $3 \mathrm{~km}$ in length and $1.5 \mathrm{~km}$ in width.

All of the flat surfaces of Mina are occupied by tents (light structures), services (water stations, bathrooms, police stations, sanitary units, some cafeterias and restaurants) and the street network. Mina is considered the largest tent city in the world and is only used for several days during the pilgrimage period from 8 to 13 Dhu al-Hijjah (Amr El Zawahry, 2008- Amr El Zawahry, 2016). 


\section{PROJECT DESCRIPTION:}

\subsection{Site Plan- layout:}

The Project consists of 6 residential buildings built on the northern slopes of Mina area that are about 20 meters high from the level of King Fahd Road south of the site area of 13 thousand $\mathrm{m}^{2}$ (without the main road leading to buildings, police services and civil defense) and a total building area of $85197 \mathrm{~m}^{2}$.The site is accessed via a sloping road to the north of the six buildings separating the project from the northern mountain, and the road continues until the entrance to the third level of the Jamarat Bridge. The area of the civil defense and police services is located at the beginning of the site, followed by The six buildings lined in a row and separated by a dead end roads for bus stopping, then the six buildings are followed by a square for the buses to turn around and a service area for the collection of waste. The level of the buildings and the valley are connected by a single stair through a camp down the valley (Figures 1 and 2).

4.2 Buildings: The buildings are distributed to two types of thirteen floors $(\mathrm{A} .3,4,5)$ and (B.1,2,6), the first three floors are designed for public spaces and services and the upper ten floors are used as residential rooms. The two types are different in the floor areas, service elements, public spaces and the number of residential rooms in typical floors. However, the original design was amended in the execution of the types of the buildings $4 \mathrm{~A}, 6 \mathrm{~A}$ and $6 \mathrm{~B}$ at the request of the Owner through minimizing a number of public spaces(elementes ) and services floors to become two floors (ground and first floors)in order to increase the number of residential rooms.(Figure 3)

Ground Floor: (Figure 3.1)The area of the ground floor in type (A) is $1134 \mathrm{~m}^{2}$ of which 345 $\mathrm{m}^{2}$ are closed spaces and the rest of the space located in the corners of the building is open to the outdoor spaces, while the ground floor area in type (B) is $861 \mathrm{~m}^{2}$ including closed spaces $314 \mathrm{~m}^{2}$ and the rest of the space is open spaces.

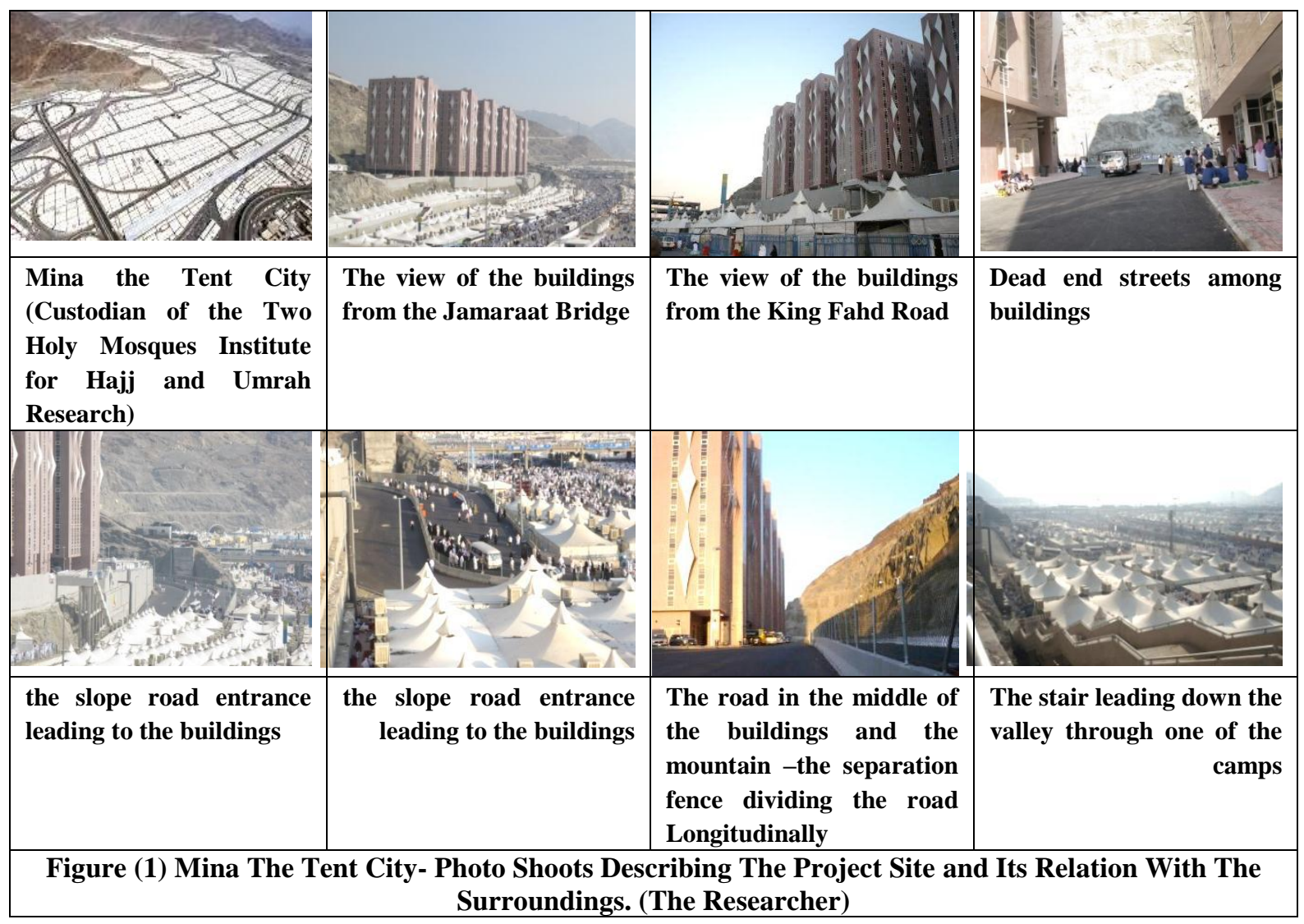




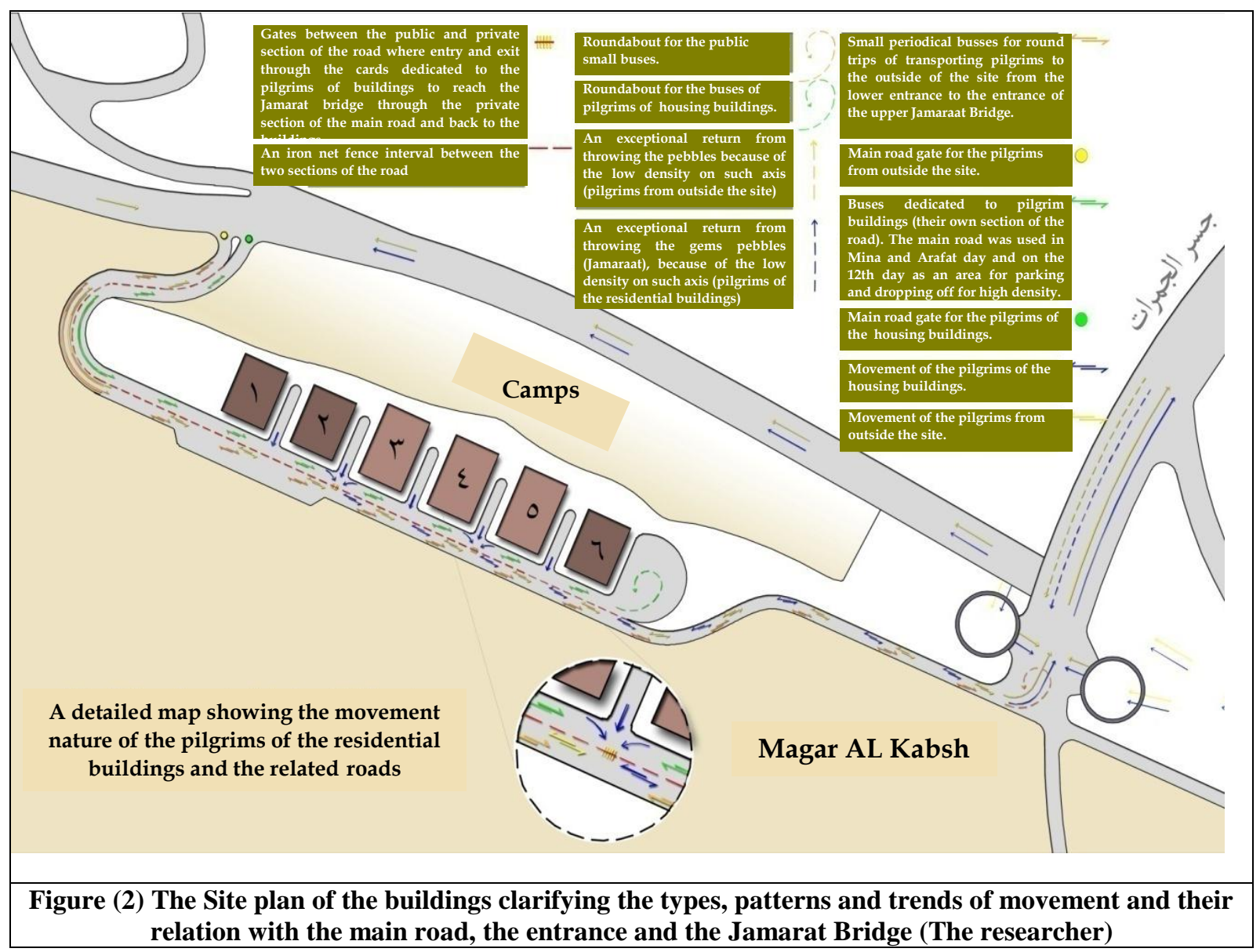

The ground floor consists of basic elements identical in the two types in terms of area and design, namely: the entrance space (Figure 5.1) - entrance hall including the elevator hall connected to the main staircase leading only to the first and second floors - two escape staircases - service entrance and a kitchen elevator up to the second floor only - technical fittings rooms - shop - a service room and a waste room that are only in type (A).

First Floor: (Figure 3.2) The area of the first floor and the remaining floors up to the twelfth floor increases to $1247 \mathrm{~m}^{2}$ in building (A) and $945 \mathrm{~m}^{2}$ in building (B), and the first floor in both types consists of the same elements with different areas as follows: seating hall (women, men) - prayer hall (women, men) - bathrooms (women, men) - technical fittings rooms elevators and elevator hall- main staircase - tow escape staircases. These elements were replaced by the elements of the second floor in the buildings (4A-5A-6B) in respect of areas of the elements and averages.

Second Floor: (Figure 3.3) consists in both models of the same elements with different areas as follows: restaurant and office (women, men) (Figure 5.2) - kitchen and its accessories management and its accessories - bathrooms (women, men) - technical fittings rooms elevators and elevator hall - main staircase - 2 escape stairs. These elements were replaced by a residential (rooms) floor in buildings (4A-5A-6B) and transferred to the first floor of which its elements were canceled.

Typical Floor (Residential): (Figure 3.4) starts from the third floor up to the twelfth floor in buildings 1,2,3 (ten floors) and from the second floor to the twelfth floor in buildings 4,5,6 (eleven floors).The residential floor consists of two rows of rooms on two corridors along the building (Figure 5.3), centered by the elevators hall, two escape staircases and the services and technical fittings rooms. The floor in the building type (A) has 16 rooms, while in building type (B) has 11 rooms and a service room, and the total number of rooms is shown in table (3). 


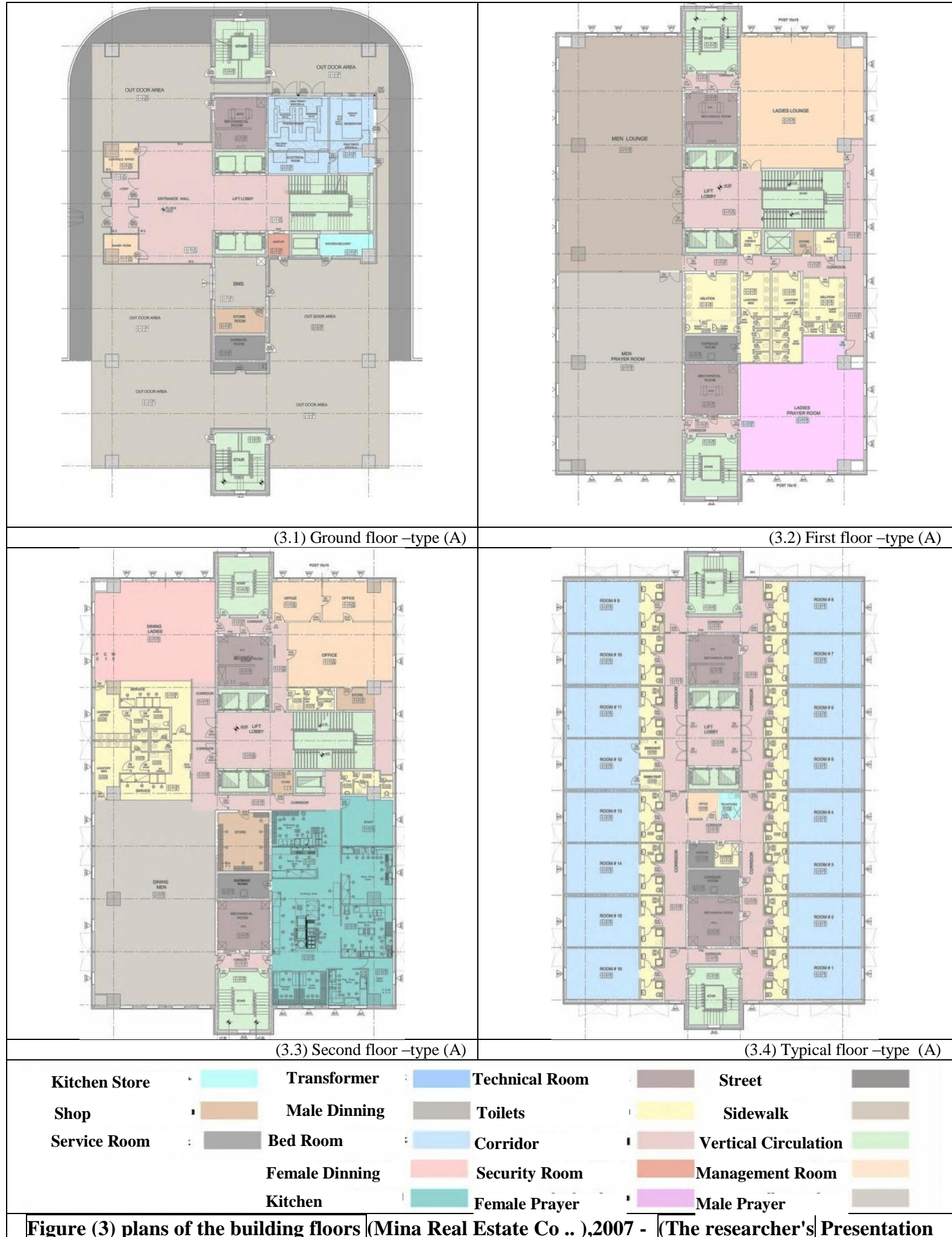

\section{Room Description:}

There are two types of rooms, each distributed to specific floors and differ on area depending on the different design of the two bathrooms attached to each room. The first type area is 36 $\mathrm{m}^{2}$ and the access to the room is through a door in the middle leading to a lobby separating the two Complete bathroom and leading to them, and the second type area is $33 \mathrm{~m}^{2}$, includes two bathrooms divided internally, one divided into two separate toilets and the other divided 
into two of separate showers (Figure 4). Each room is furnished through different styles pursuant to the number of pilgrims and the amount paid as there are rooms furnished with mattresses or a mattress chair $(60-80 \mathrm{~cm}$ in width) on the floor, placed on two opposite rows perpendicular to the two sides of the room (number of 12-20) (Figure 5.4) and other rooms (V.I.P) furnished with beds with numbers of 8 and less.

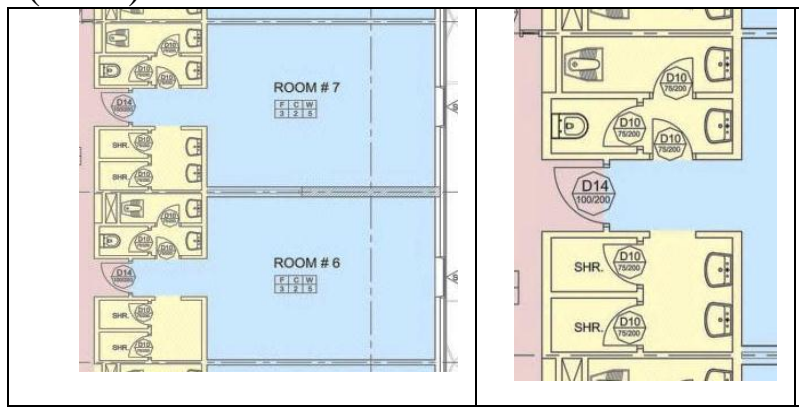

(1) room of two divided bathrooms- details of bathrooms
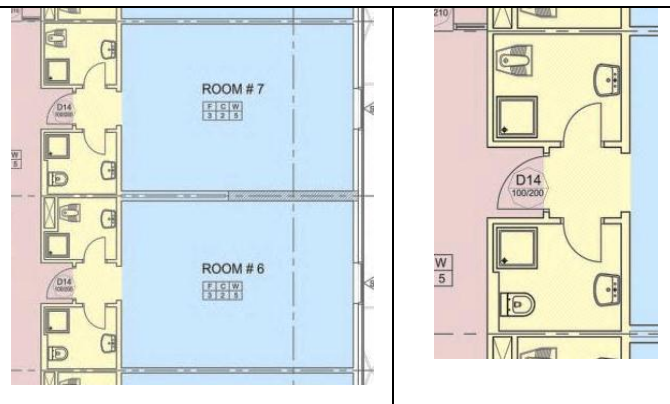

(2) room of two complete bathrooms- details of bathrooms

Figure (4)Plans of the rooms and system of the bathrooms (The researcher)

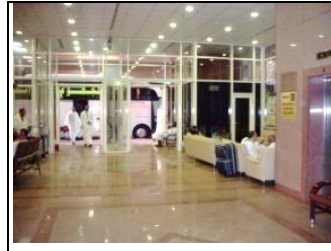

(5.1) Building entrance

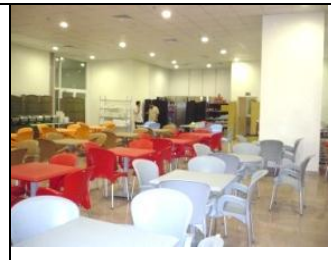

(5.2) Restaurant

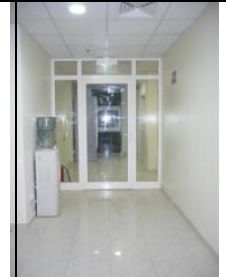

(5.3) Floor corridors

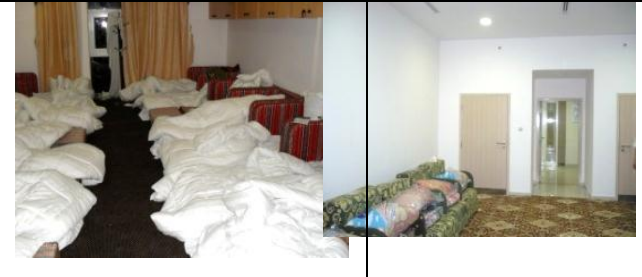

(5.4) levels and methods of furnishing the rooms (mattress - mattress chair)

4.3 Details And Rates Of The Project:

Main details are as follows: Table (3)

Table (3) Details and rates of the Project: (The researcher

\begin{tabular}{|c|c|c|c|}
\hline & Building type (A) & Building type(B) & Total Project \\
\hline $\begin{array}{l}\text { The number of persons per room according to } \\
\text { the number specified by the Owner }\end{array}$ & 16 persons/ room & 16 persons/ room & $\begin{array}{l}16 \text { persons / } \\
\text { room }\end{array}$ \\
\hline $\begin{array}{l}\text { The number of persons in the project by } \\
\text { counting } 16 \text { persons per room }\end{array}$ & 5440 persons & 8128 persons & 13568 persons \\
\hline \multirow[t]{2}{*}{ The number of persons in the building } & $\begin{array}{l}\text { (A4-A5) } 2784 \\
\text { persons }\end{array}$ & $\begin{array}{ll}(\mathrm{B} 1-\mathrm{B} 2) & 1760 \\
\text { persons } & \end{array}$ & --- \\
\hline & (A3) 2560 persons & (B6) 1920 persons & --- \\
\hline Total area of the buildings floors & $48294 \mathrm{~m}^{2}$ & $36903 \mathrm{~m}^{2}$ & $85197 \mathrm{~m} 2$ \\
\hline Total area of the building floors & $16098 \mathrm{~m}^{2}$ & $12301 \mathrm{~m}^{2}$ & ---- \\
\hline $\begin{array}{l}\text { The number of rooms in the buildings of each } \\
\text { type }\end{array}$ & 508 rooms & 340 rooms & 848 rooms \\
\hline \multirow[t]{2}{*}{ The number of rooms in the building } & $\begin{array}{l}\text { (Building 4-5)174 } \\
\text { rooms }\end{array}$ & $\begin{array}{l}\text { (Building 1-2)110 } \\
\text { rooms }\end{array}$ & ---- \\
\hline & $\begin{array}{l}\text { (Building 3) } 160 \\
\text { rooms }\end{array}$ & $\begin{array}{l}\text { (Building 6) } 120 \\
\text { rooms }\end{array}$ & \\
\hline $\begin{array}{l}\text { The floor area ratio (FAR) (total floors area to } \\
\text { the lot area ( equal to coverage area) ( } 13 \text { floors) }\end{array}$ & $1419 \% \quad(14.19)$ & $1419 \% \quad(14.19)$ & $\begin{array}{l}1419 \% \\
(14.19)\end{array}$ \\
\hline $\begin{array}{l}\text { Total floors area to the site area of the } \\
\text { building (building land, sidewalks, and intra- } \\
\text { streets). }\end{array}$ & $713 \%$ & $713 \%$ & $713 \%$ \\
\hline $\begin{array}{l}\text { Location land area dedicated for the buildings } \\
\text { without the main road }\end{array}$ & ---- & --- & 1,3Hectare \\
\hline Length of the road leading to the buildings & ---- & +--- & 250 meter \\
\hline Number of buildings & 3 buildings (3-4-5) & 3 buildings (1-2- & 6 buildings \\
\hline
\end{tabular}




\begin{tabular}{|c|c|c|c|}
\hline & & 6) & \\
\hline Ground floor area & $\begin{array}{l}1134 \mathrm{~m} 2 \text { (closed } \\
345 \mathrm{~m} 2)\end{array}$ & $\begin{array}{ll}853 & \mathrm{~m} 2 \\
314 \mathrm{~m} 2)\end{array}$ & \\
\hline Floor area (1 to 12) & $1247 \mathrm{~m} 2$ & $954 \mathrm{~m} 2$ & \\
\hline Number of floors & $\begin{array}{l}13 \text { (ground floor } \\
+12)\end{array}$ & $\begin{array}{l}13 \text { ( ground floor } \\
+12 \text { ) }\end{array}$ & \\
\hline $\begin{array}{l}\text { Number of residential floors (residential } \\
\text { rooms) }\end{array}$ & $\begin{array}{l}\text { Building (4-5) } 11 \\
\text { floors }\end{array}$ & $\begin{array}{l}\text { Building (1-2) } 10 \\
\text { floors }\end{array}$ & \\
\hline & $\begin{array}{l}\text { Building (3) } 10 \\
\text { floors }\end{array}$ & $\begin{array}{l}\text { Building (6) } 11 \\
\text { floors }\end{array}$ & \\
\hline Number of rooms in the buildings of each type & 508 rooms & 340 rooms & 848 rooms \\
\hline $\begin{array}{l}\text { Percentage of residential floors area to the } \\
\text { total floors area of the building. (in case of } 10 \\
\text { residential floors) }\end{array}$ & $81 \%$ & $81 \%$ & $81 \%$ \\
\hline $\begin{array}{l}\text { Percentage of public activities floors (ground, } \\
\text { first and second) to the total floors area of the } \\
\text { building. (10 residential floors) }\end{array}$ & $19 \%$ & $19 \%$ & $19 \%$ \\
\hline $\begin{array}{l}\text { Percentage of residential floors area to the } \\
\text { total floors area of the building. (in case of } 11 \\
\text { residential floors) }\end{array}$ & $88 \%$ & $88 \%$ & $88 \%$ \\
\hline $\begin{array}{l}\text { Percentage of public activities floors (ground } \\
\text { and first) to the total floors area of the } \\
\text { building. (11 residential floors) }\end{array}$ & $12 \%$ & $12 \%$ & $12 \%$ \\
\hline $\begin{array}{l}\text { Percentage of residential room areas to total } \\
\text { building floors area. }\end{array}$ & $33 \%-36 \%$ & $33 \%-36 \%$ & $34.5 \%$ \\
\hline $\begin{array}{l}\text { Percentage of residential rooms area to total } \\
\text { residential floors area. }\end{array}$ & $42 \%$ & $42 \%$ & $42 \%$ \\
\hline $\begin{array}{l}\text { The number of persons / square meters of the } \\
\text { site of the building (building land, sidewalks, } \\
\text { and intra-streets). }\end{array}$ & - & - & $\begin{array}{l}1.09 \\
\text { pilgrim/m2 }\end{array}$ \\
\hline $\begin{array}{l}\text { The number of persons / square meters of land } \\
\text { of the building (lot area equal to lot coverage } \\
\text { area). }\end{array}$ & - & - & 2.3 pilgrim $/ \mathrm{m} 2$ \\
\hline $\begin{array}{l}\text { The person's share in the land area of the } \\
\text { building. }\end{array}$ & $0.41-0.44 \mathrm{~m} 2$ & $0.44-0.48 \mathrm{~m} 2$ & $0.44 \mathrm{~m} 2$ \\
\hline $\begin{array}{l}\text { The person's share in the site area of the } \\
\text { building (building land, sidewalks, and intra- } \\
\text { streets). }\end{array}$ & - & - & $1.01 \mathrm{~m} 2$ \\
\hline $\begin{array}{l}\text { The person's share in total building floors } \\
\text { area. }\end{array}$ & $5.78-6.93 \mathrm{~m} 2$ & $5.78-6.93 \mathrm{~m} 2$ & $6.25 \mathrm{~m} 2$ \\
\hline The person's share in room area. & $2.07 \mathrm{~m} 2$ & $2.07 \mathrm{~m} 2$ & $2.07 \mathrm{~m} 2$ \\
\hline $\begin{array}{l}\text { The rate of persons to the bathrooms of } \\
\text { residential room }\end{array}$ & $\begin{array}{l}8 \text { persons } \\
\text { bathroom }\end{array}$ & $\begin{array}{l}8 \text { persons } / \\
\text { bathroom }\end{array}$ & $\begin{array}{l}8 \text { persons / } \\
\text { bathroom }\end{array}$ \\
\hline The person's share in the restaurant area. & $\begin{array}{l}0.12-0.13 \mathrm{~m} 2 / \\
\text { person }\end{array}$ & $\begin{array}{l}0.11-0.12 \mathrm{~m} 2 / \\
\text { person }\end{array}$ & $\begin{array}{l}0.12 \mathrm{~m} 2 \\
\text { person }\end{array}$ \\
\hline The person's share in the kitchen area. & $\begin{array}{l}0.11-0.12 \mathrm{~m} 2 / \\
\text { person }\end{array}$ & $0.07 \mathrm{~m} 2 /$ person & $0.1 \mathrm{~m} 2 /$ person \\
\hline $\begin{array}{l}\text { The person's share in the prayer hall area } \\
\text { (According to the original design). }\end{array}$ & $\begin{array}{l}0.12-0.13 \mathrm{~m} 2 / \\
\text { person }\end{array}$ & $\begin{array}{l}0.21-0.23 \mathrm{~m} 2 / \\
\text { person }\end{array}$ & $\begin{array}{l}0.18 \mathrm{~m} 2 \\
\text { person }\end{array}$ \\
\hline $\begin{array}{l}\text { The person's share in seating halls area } \\
\text { (According to the original design). }\end{array}$ & $\begin{array}{l}0.15-0.16 \mathrm{~m} 2 / \\
\text { person }\end{array}$ & $\begin{array}{l}0.21-0.23 \mathrm{~m} 2 / \\
\text { person }\end{array}$ & $\begin{array}{l}0.19 \mathrm{~m} 2 \\
\text { person }\end{array}$ \\
\hline public toilets per persons number. & $\begin{array}{l}\text { Toilet/ 233-253 } \\
\text { persons }\end{array}$ & $\begin{array}{l}\text { Toilet / } 176-192 \\
\text { persons }\end{array}$ & $\begin{array}{l}\text { Toilet / } 215 \\
\text { persons }\end{array}$ \\
\hline elevators rate per the number of persons. & $\begin{array}{l}\text { Elevator/ } \\
\text { 696persons }\end{array}$ & $\begin{array}{l}\text { Elevator/ } 440- \\
\text { 480persons }\end{array}$ & $\begin{array}{l}\text { Elevator/ } \\
\text { 565persons }\end{array}$ \\
\hline
\end{tabular}




\section{CONSIDERATIONS AND DETERMINANTS OF THE RESEARCH:}

In order to understand and evaluate the pilgrimage experience through the housing buildings in Mina, the Research findings and its resulting recommendations and design directives, the following considerations and determinants shall be taken into account (The researcher):

- The experience of the pilgrims housing in the mountain slopes of Mina area is considered the first of its kind at the pilgrimage level and hence the whole world.

- No previous experience in such projects includes such huge number of users.

- No previous experience in the management of the mechanisms of the pilgrims' accommodation in multi-floor residential (hotel) buildings in Mina as the previous experience is represented in the management of the mechanisms of the pilgrims' accommodation in the (camps) tents of Mina.

- The huge difference and contrast between the management of the mechanisms of the pilgrims accommodation horizontally (one ground floor with tents) and the management of the pilgrim accommodation and services vertically.

- The research was based on the analysis of and linking the two studies (surveys) data of the pilgrimage of $1429 \mathrm{AH}$ and the pilgrimage of $1430 \mathrm{AH}$ (as the first study paved the way for and supported the second study) in order to conclude the findings of the Research and propose the design and planning recommendations, directives and principles. The focus of the research is on the site and buildings in general and the building type (A) in particular. (The researcher participated in the two studies).

- The previous proposals for the systems of sheltering the pilgrims in Mina area: - applicable structures - metal shelves - mobile cabins - metal scaffoldings (multi-floor tents) - multi-floor structures (buildings) in the flat area of Mina area which is an unacceptable proposal for Sharia controls (Central Hajj Committee, 1419 AH).

- The research presents the rates and criteria related to the tents in Mina and the hotels of pilgrims' housing in Makkah and Madinah. The research also calculated all the rates of the pilot project buildings for a comparison to support the evaluation of buildings, draw conclusions and make recommendations and design directives (guidelines).

- Many variables contributed to the opinions of the pilgrims including:

- Difference and contrast in the level of campaigns and building management.

- Change or cancellation of some of the functions of the building spaces and the different level of furnishing (furniture) from one building to another and between the floors and rooms of the same building.

- The limited period of stay of the pilgrims and the lack of previous experience make the views of pilgrims affected by certain events only.

- Number of pilgrims in the room (crowding rate) where the preparation of pilgrims in the room varies from building to building and from one floor to another according to the different economic levels of pilgrims.

- In several cases, the opinions of pilgrims represent the views of their roommates. This is evident in the fact that several pilgrims fill in one questionnaire to represent all of them, which makes the questionnaire rate higher than it really is (Pilgrimage season 29).

- The comparison by the pilgrims to the experience of staying in the buildings of Mina and the experience of staying in the hotels of Makkah and Madinah with the least capacity by a large difference (about 25\%).

- Pilgrims (especially those who did not perform pilgrimage in tents before) express their views of the elements of the building in terms of areas and rates as considered the fundamental elements in hotel housing, although those elements do not exist in the pilgrimage tents in Mina.

- When evaluating rates, areas, individual shares and service systems for buildings, matters related to the accommodation in (camps) tents are taken into consideration such as:

- Share of the individual in the camps is reduced in most camps to increase the absorptive capacity to less than one square meter (questionnaire of Motawifs (Regulators) ) (average net area of one pilgrim from the space of the tent equals $1.08 \mathrm{~m}^{2} /$ pilgrim) (Urban Observatory, $1432 \mathrm{AH})$.

- In the tents (camps) all activities are practiced in the same place (sleeping - sitting - eating - prayer). 
- Toilets are collected and are common among the camps at a rate of about 81 persons for each toilet (analysis of maps of some camps in Mina (The researcher)) and ( 11.4 toilets / 1000 persons (87.7 persons / toilet) according to the Urban Observatory of Hajj, $1432 \mathrm{AH}$ )

- Movement between tents and toilets is in outdoor corridors.

- Air conditioning systems (desert) are of weak capacities, especially in high temperature seasons (the limited V.I.P camps are different from the above by excellence in some or all items). (Figure 6)

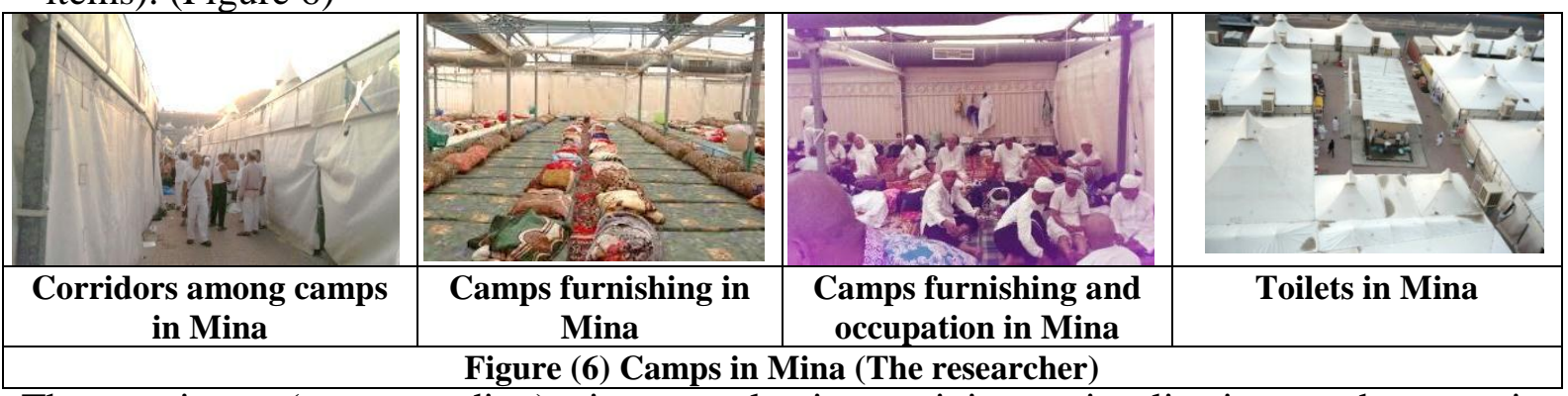

The consistent (corresponding) views, evaluation, opinions, visualizations and suggestions will be presented as a general summary for all parties, subjects and elements of the evaluation through the two studies. In case there are some observations or information about either of the two studies, they will be referred to as (Pilgrimage season( hajj29)) or (Pilgrimage season 30( hajj30)).

- The average number of persons in the room in Makkah and Madinah hotels during the minor pilgrimage (Umrah) or pilgrimage period ranges from 3 to 5 persons and the average number of persons to the elevators ranges from 150 to 200 persons / elevator (field survey for a group of hotels in Makkah and Madinah by the The researcher) according to the (Saudi Commission for Tourism and Antiquities, 1433 AH- Licenses Department, 1437 AH) the rates (which are within the assessment points and the determination of the number of stars for hotels in Makkah and Madinah) are as follows:

$\circ$ The maximum number is 5 persons per room, room size is $30 \mathrm{~m}^{2}$ including entrance and The bathroom, and is not below than $24 \mathrm{~m}^{2}$ for the five stars and $14 \mathrm{~m}^{2}$ for the three stars. The bathroom area is not less than $5 \mathrm{~m}^{2}$ for the five star room and not less than $3 \mathrm{~m}^{2}$ for the lower levels (Area per person in order is 6- 5- $3 \mathrm{~m}^{2}$ approximately)

$\circ$ The five star restaurant area is $75 \mathrm{~m}^{2} / 100$ persons $\left(0.75 \mathrm{~m}^{2} /\right.$ person $), 50-75 \mathrm{~m}^{2} / 100$ persons $\left(5-75 . \mathrm{m}^{2} /\right.$ person) for the four stars and $50 \mathrm{~m}^{2} / 100$ persons $\left(0.5 \mathrm{~m}^{2} /\right.$ person $)$ for the three stars.

$\circ$ Area of multi-purpose halls is $75 \mathrm{~m}^{2} / 100$ persons $\left(0.75 \mathrm{~m}^{2} /\right.$ person $)$, in addition to another multi-purpose hall at the rate of $40 \mathrm{~m}^{2} / 100$ persons.

○ Elevator / 50 rooms (compatible with field survey).

$\circ$ Provision of an independent services entrance and shops in case of the lack of contact with a commercial market.

- The peak times for the movement of pilgrims within the building are at meal times (3 times), prayer times (5 times), check in times and times of going to the performance of pilgrimage.

- In the study (Hajj 29), only four buildings (1, 2, 3 and 4) were operated where the occupancy rate varied from one building to another and the sample of pilgrims questionnaire was 5\%.In the study (Hajj 30), the occupancy rate was full for six buildings and the sample rate was $10 \%$.

\section{ELEMENTS AND SUBJECTS OF STUDY AND THE USED EVALUATION TOOLS:}

\subsection{Elements and subjects of evaluation in the study:}

- First: Elements of evaluation: The evaluation was carried out through the various evaluation tools for all elements of the site, and building (spaces) in terms of area, furnishing and its location in the building and their interrelations, mutual effects and suitability for the performance of activities and their positive and negative sides. The elements of the evaluation are: - Site, transportation, movement and external spaces - entrance, entrance hall and elevator 
hall - seating hall - prayer hall - dining hall - kitchen - residential rooms - toilets and bathrooms - elements of vertical and horizontal circulation - services, technical fittings and finishes.

Second: Subjects of Evaluation: The evaluation subjects of the pilgrimage experience through accommodation in buildings in Mina are:- Arranging the days of the pilgrimage according to the severity and proportions of problems - Arranging the problems according to their severity - Preference of the general appearance of Mina (tents, buildings, mixture) - The most suitable way of expansion in the construction on the slopes of the mountains of Mina Suitability of buildings with the behavior of pilgrims - Height of the buildings - Suitability of the buildings with the appearance of mountains and tents.

6.2 Tools of evaluation used in the study are :

- Analysis of the plans and maps of the site and buildings and the calculation of associated rates.

- Survey the opinions of pilgrims through questionnaire forms and direct meetings, measure their satisfaction, and monitor and analyze their behavior, opinions, views and suggestions.

- Survey the opinions of the operators, Motawifs (Regulators ) and project and buildings managers through the questionnaire forms and monitor and analyze their opinions, views and suggestions.

- Survey the opinions of the relevant entities.

- Coexistence, field observation and documentation and authentication by the research team.

\section{DESCRIPTION AND EVALUATION (OF EVALUATION PARTIES) OF THE SITE AND BUILDING ELEMENTS ALONG THE DAYS OF PILGRIMAGE AND OF THE SUBJECTS OF EVALUATION :}

\subsection{Site, transportation and movement:}

The inability of the site to absorb buses where the number of buses to be absorbed is estimated at 260 buses (by calculating the buildings absorption for 13 thousand pilgrims and the bus absorption of 50 pilgrims), which requires dividing the pilgrims into 8 or 9 Regiments (The researcher) and this is difficult especially with the incompatibility of bus traffic at the entrance with the off-site buses on King Fahd Road.

The site's lack of capacity and its problems are illustrated below: (Figure 7)

O It was evident on the 8th of Dhul-Hijjah that the area of the roads, waiting stations (overnight stay) and places of dropping-off and picking-up allocated to buildings were insufficient, and there was also over-crowdedness, difficult of buses traffic as it stops away from buildings, and the over-crowdedness of pilgrims and their luggage in front of the buildings, especially with the convergence of buses arrival.

o Buses occupied the entire site by the end of day 8 and overnight until day 9 to go to Arafat, where buses occupied the road section allocated to the buildings and the dead-end streets among the buildings as well as the road section allocated for the pedestrian pilgrims .Security authorities prevented buses from entering the site on the $10^{\text {th }}$ and $11^{\text {th }}$ of Dhul-Hijjah (Hajj 30). Buses also occupied the entire road of the buildings on the 12th of Dhul-Hijjah. (Hasty pilgrimage).

○ Occupation of irregular pilgrims for both sides of the pedestrian road and the site ( sitting , accommodation and overnight) (started on the $10^{\text {th }}$ day before the pilgrims go to throw pebbles (aljamarat ) at the days of Tashreeq), the overlap of the buses traffic with the pedestrians, and the interference of the bus stops among buildings with other activities such as prayer and movement of services.

$\circ$ The absence of a separate exit and entrance to the buses and the difficulty of turnabout, especially for those who occupied the pedestrian side of the road, and the absence of emergency exits from the site, except the entrance of the site and a stair linking the site level with the level of the lower road (King Fahd), Through one of the camps down the site, which was not activated during the pilgrimage season; and the lack of effective means of transporting pilgrims from the entrance of the site to the buildings as well as from Mina to Makkah during the days of Tashreeq to circumambulate in the Haram. 


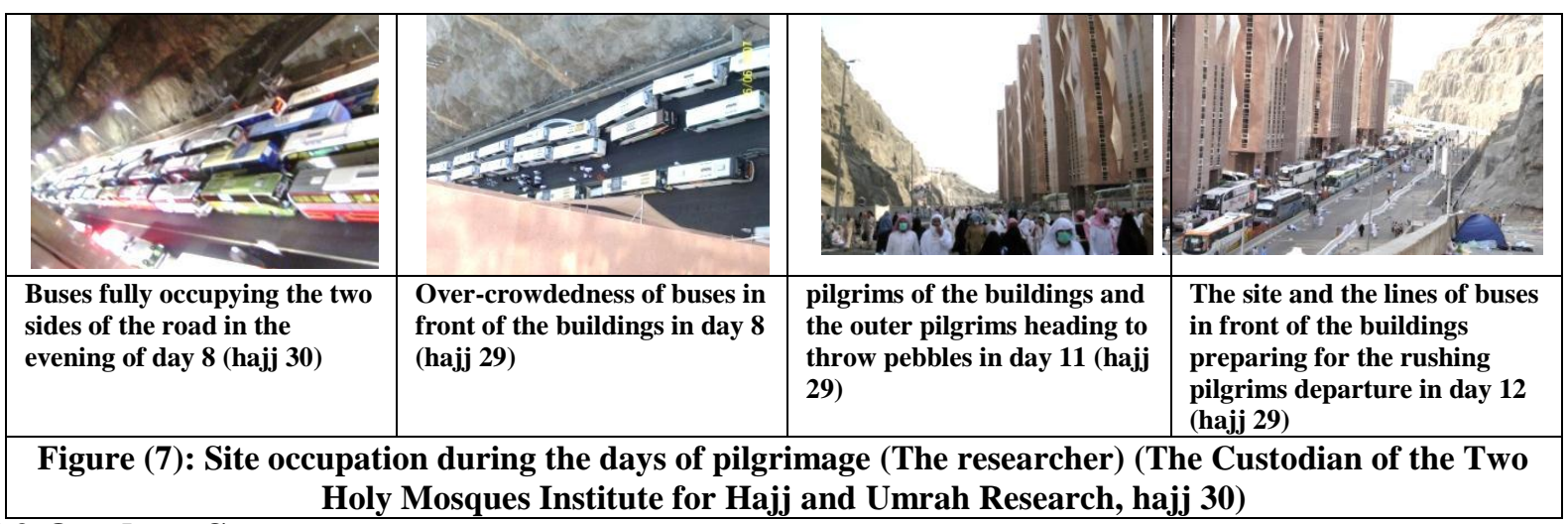

\subsection{Outdoor Spaces:}

The outdoor spaces were represented in the open areas down the buildings and the interspaces among the buildings and surrounding it, the sidewalks and the bus stops; the area separating the buildings and the fence overlooking the valley of Mina, which has been used as a breathing space for pilgrims, in the activities of prayer and sitting and the cultural and social activities and seminars where the officials of some buildings provided seats and tables that were used in the buildings of which restaurant were cancelled as a place to eat, and thus those places represented a compensation for the inadequacy or cancellation of the public activities in the buildings (prayer place, seating areas, restaurant, seminar places) (Figure 8). All the notes and evaluations of the participating parties were as follows:

- Lack of services on site or ground floor (toilets - ablution places - mosque - cafeteria barber - ATM - laundry).

- Insufficient places of prayer down the buildings and the extension of the prayer to the sidewalks and inter-streets and the overlap of the sounds of prayers, seminars and lectures between the buildings. Opposition of the movement of services, dropping-off, picking-up, buses, and the movement of pilgrims and prayer.

- Occupying outdoor spaces with the inappropriate occupations of temporary storage and garbage containers.

-Non-shading of the outdoor spaces, which makes it difficult to sit in it at the day, and the high stone fence on Mina Valley reduced the chances of the pilgrims' joy who preferred the low parts of the fence topped by a metal fence.

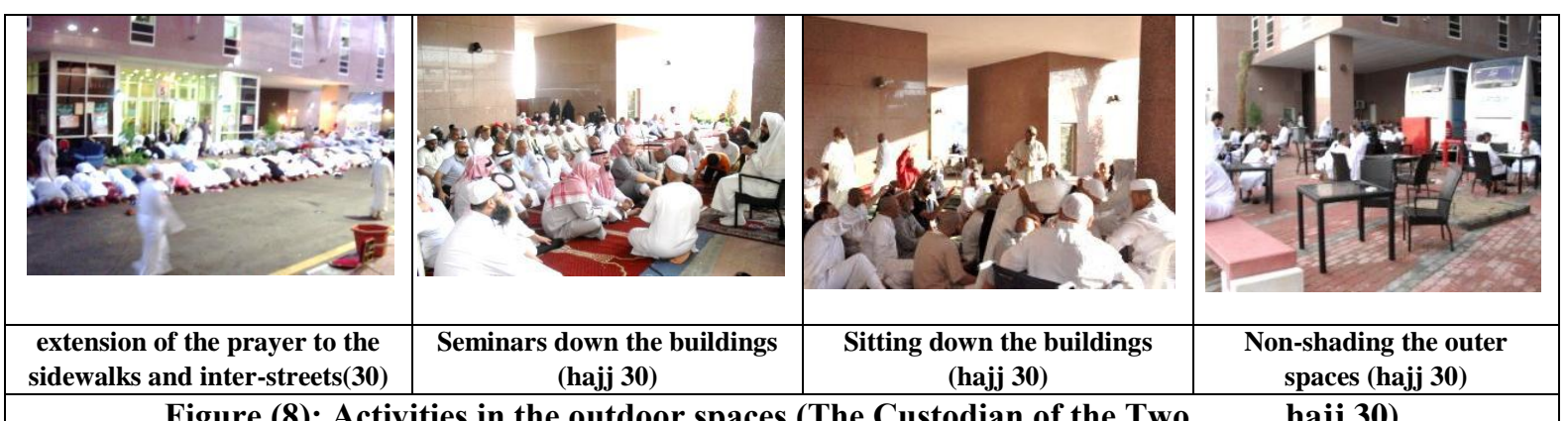

\subsection{Buildings:}

\subsubsection{Entrance, entrance hall, elevator hall, elevators (Ground floor)}

- The space is small and the capacity is insufficient for the pilgrims' numbers and activities (reception - seating - check in - luggage transport - movement of services for lack of services entrance and elevator - movement of pilgrims - storing supplies in the empty space down the main stair for lack of storage places).

- The most important drawbacks are the lack of toilets - no connection between the entrance hall and the escape stairs (the main element of movement in the whole building) - the inadequate reception and seating areas and the lack of a cafeteria.

- Insufficient number and capacity of elevators, which was reflected in the slow pace of check-in operations and the movement of pilgrims and increased the congestion and crowding 
of pilgrims in the entrance hall and elevator hall, especially with the convergence of the times of pilgrims' arrival and peak times (Figure 12.1,2).

\subsubsection{Functional elements (Public Activities Spaces):}

- Some of the common features and observations of all functional spaces: The space is small and its capacity insufficient to meet the large numbers of pilgrims in succession during the main use times that led to congestion and crowding of spaces, which represented a large burden on the elevators (of limited number and capacity) and elevator halls, which forced the pilgrims to use emergency staircases for frequent usual movement (taking into account that a large percentage of pilgrims did not use those spaces for these reasons) (Figure. 9 ).

-Pilgrims (hajj 29) stated that they did not use the public spaces (elements ) for the above reasons and that the location of the spaces are not suitable in the building and that the spaces area are insufficient as the percentage shown in the graph. Figure $(10,11)$.

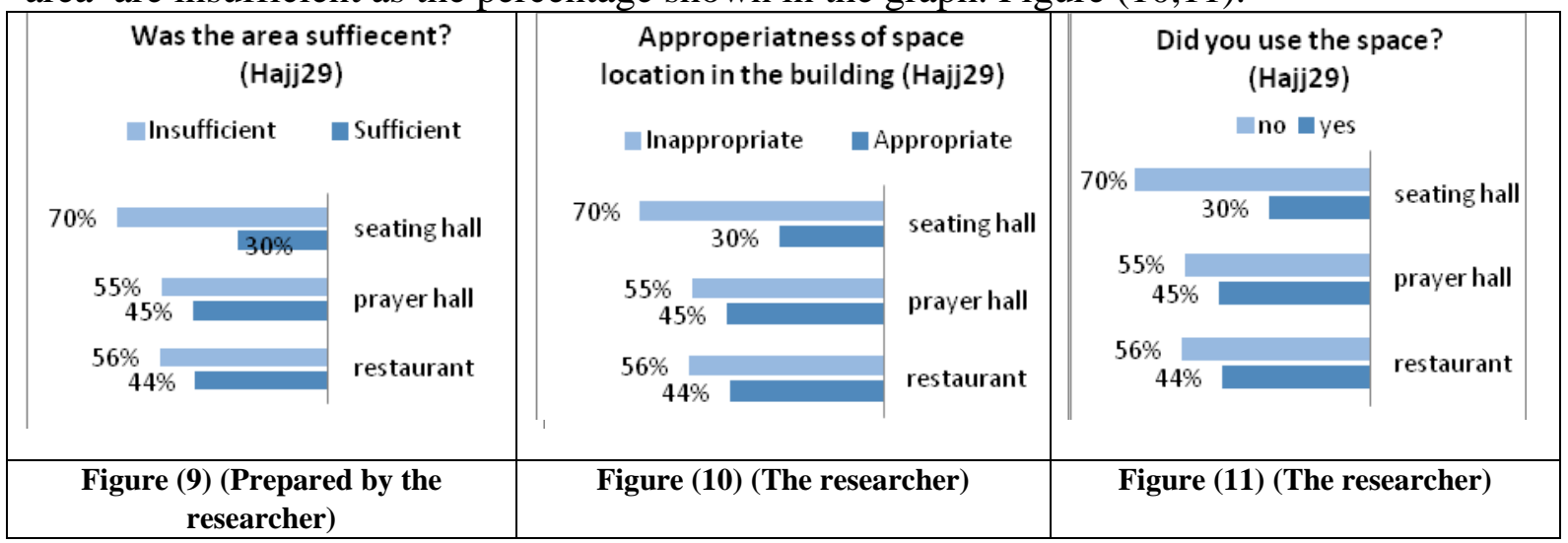

-Pilgrims (hajj 30) stated that they did not use the public spaces (44\% for the prayer hall, $23 \%$ for the dining hall) - the location of the spaces is not suitable in the building (51\% for the prayer hall, $52 \%$ for the dining hall) and that the spaces area is insufficient (61\% for the prayer hall, $44 \%$ for the dining hall). -Overall, $80 \%$ of the pilgrims preferred to have public activities spaces distributed on the floors because they are not suitable in the lower floors (as in hotels) due to the high occupancy rate of the building and the reliance on vertical movement.

\section{- Seating hall (Salons and living rooms):}

It was cancelled executively in buildings $(4,5,6)$ to be replaced by the rooms and operationally in buildings $(1,2,3)$ by the operators and employed in other common activities (restaurant - storage - sleeping area for workers - prayer), pilgrims used the limited seating area in the entrance hall, or the restaurant and the prayer hall if they are not canceled or at the outdoor spaces down and around the buildings. the negative views was that there were no halls to sit or hold seminars and lectures, either grouped or distributed on the floors (Figure. $12.3,4)$.

\section{- Prayer Hall:}

- In the buildings with a prayer area $(1,2,3)$, the prayer is held on several consecutive groups and it is extended to the spaces adjacent to the prayer hall (restaurant - storage places sleeping area of workers) and the prayer is overlapped with the furnishing elements- Seminars and lectures are held at the prayer hall for the lack of a place dedicated for them - A large percentage of pilgrims pray in rooms and corridors in the residential floors and open spaces down the building (Figures 12.5, 6).

- In the buildings (4-5-6), which did not have a prayer hall in design and execution, the prayer is partially done in the cancelled dining hall (functionally), which is also used in workers' sleep and in storage. Basically, the open spaces down the buildings were allocated for prayer, which extended to occupy the sidewalks, surrounding spaces and bus stops where the sounds of prayers, seminars and lectures overlapped among the buildings. There are no covered places for women to pray, in addition to the lack of toilets or ablution areas on the ground floor.

\section{- Dining Hall- Kitchen:}


The way of using the dining hall became different or it might not be used and converted for another activity, as well as the style of catering, which differed from building to building. A large proportion of pilgrims do not eat food in the dining hall for congestion. The use of dining halls in seating and praying activities and holding lectures and seminars, as well as the inadequacy of catering in the residential floors (open buffet and the setting up of tables in the corridors or the provision of meals in rooms, which is a huge burden on the elevators) without providing special dining halls and service elevators and a kitchen elevator. In some buildings, tables were set up to serve food in the outer spaces down the buildings (Figures 12.7, 8).

\begin{tabular}{|c|c|c|c|}
\hline $\begin{array}{l}\text { (12.1) Congestion in the } \\
\text { entrance hall (hajj 29) }\end{array}$ & $\begin{array}{l}\text { (12.2) Congestion in the } \\
\text { entrance hall (hajj 30) }\end{array}$ & $\begin{array}{l}\text { (12.3) Prayer and storage } \\
\text { in the seating halls (hajj } \\
\text { 30) }\end{array}$ & $\begin{array}{c}\text { (12.4) Sleeping of workers } \\
\text { and storage in the seating } \\
\text { halls (hajj } 30)\end{array}$ \\
\hline- & & 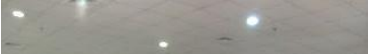 & \\
\hline (12.5) Prayer hall hajj 29) & $\begin{array}{l}\text { (12.6) Congestion before } \\
\text { the prayer hall from the } \\
\text { side of the entrance in the } \\
\text { seating hall (hajj 29) }\end{array}$ & $\begin{array}{l}\text { (12.7) Crowdedness and } \\
\text { congestion in the dining } \\
\text { hall (hajj 29) }\end{array}$ & $\begin{array}{l}\text { (12.8) Dining tables set up } \\
\text { in the spaces down the } \\
\text { building (hajj 30) }\end{array}$ \\
\hline Figure (12) Occupation an & $\begin{array}{l}\text { utilization of the building sp } \\
\text { The Custodian of th }\end{array}$ & $\begin{array}{l}\text { s during the pilgrimage } \\
\Gamma \text { wo ..... , hajj 30) }\end{array}$ & (The researcher, hajj 29 - \\
\hline
\end{tabular}

- $45 \%$ of resident pilgrims (Hajj 29) determined that the food waiting time is long (an average of 18 minutes) as well as the time taken to find a seat (average of 12 minutes). The most crowded times were lunch and dinner (40\% - 44\%), and 57\% of them found the attached toilets are inadequate.

- The kitchen represented a large part of the problem of the towers because of the small area and poor operational capacity to do the necessary tasks associated with high occupancy rates in the building, and the lack of the access of kitchen elevator to all floors.

\subsubsection{Residential Rooms:}

- Residential rooms are the most important elements of evaluation because of their direct link and significant impact to the pilgrims accommodation, as it is a qualitative leap for the accommodation in the tents of Mina in terms of area and rate of toilets for the number of pilgrims, where two bathrooms allocated for each room (per specific and limited group of pilgrims) and in terms of finishing and fitting (Figure 13.1)

- (Hajj 29): The number of persons per room ranges from 12 to 20 pilgrims depending on the cost of accommodation where there are (V.I.P) rooms where the number of persons are 6 or less, and the assessment and satisfaction of pilgrims about the room and its area are related to the number of persons in the room where $34 \%$ of pilgrims stated that the area is small, $54 \%$ stated that the area is medium and the rooms of less than 16 persons are acceptable and satisfactory for $86 \%$ of pilgrims and the fewer the number of persons the more increased satisfaction rate is.

- (Hajj 30): The rooms with 16 persons or more represented 49\%, the rooms with 16 persons represented $38.4 \%$, while the rooms with 6 persons and less were $8 \%$, and the rooms with from 7 to 12 persons represented $27 \%$. Pilgrims said that rooms with 16 or more persons are crowded, while the rooms of 14 persons are suitable and acceptable. The majority think that the number of 12 persons per room is very appropriate, and $83.6 \%$ of the pilgrims pointed out to the appropriateness of the room in general. Negative observations were, in order of importance, as follows: lack of control of air conditioning from inside the room, huge number of pilgrims in the 
room, the lack of furnishing supplements, and Lack of privacy because of the extension of window openings from the ceiling to the floor of the room.

- Area per person in the room (net without bathrooms and entrance), which has 20 individuals is $1.66 \mathrm{~m}^{2}$, area per person in the room with 12 persons is $2.76 \mathrm{~m}^{2}$, and in rooms with 8 persons is $4.14 \mathrm{~m}^{2}$ (VIP), while the area per person in rooms with 16 persons (the largest proportion determined by the Owner) is $2.07 \mathrm{~m}^{2}$ (double the area per person in the tents of Mina - taking into account the addition of the share of person in various elements and building spaces that are not available in Mina camps).

- Pilgrims had to eat and pray in the rooms due to problems related to the restaurant, the prayer area and the elevators (Figure 13.2, 3, 4).

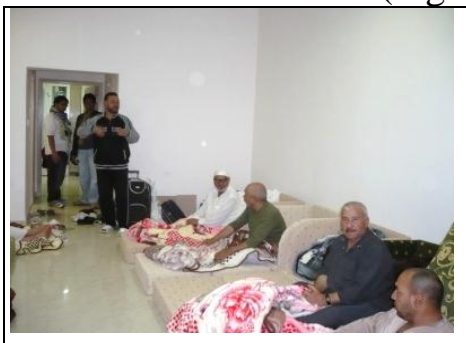

(1) Furnishing and occupancy style in the rooms (Hajj 29)

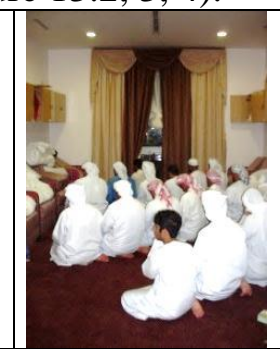

(2) Prayer

inside the rooms (Hajj

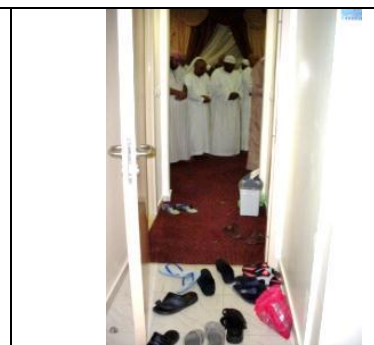

(3) Prayer inside the rooms- shoes in front of the room entrance (Haji 30)

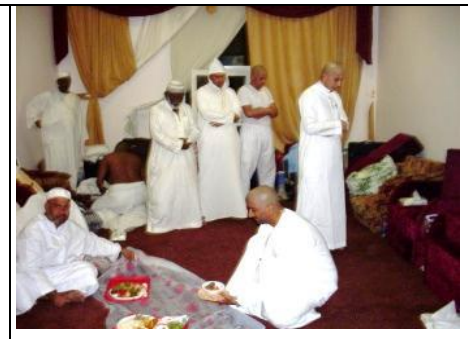

(4) Eating in the rooms (Hajj 30)

Figure (13): Occupying and using the rooms throughout the pilgrimage days (The researcher, Hajj 29 The Custodian of the Two ......(, Hajj 30$)$

- Room bathrooms: It is one of the most important elements of the evaluation, which was characterized in terms of rates, fittings and finishes and in terms of allocation to a specific number of persons (residents of each room), where two bathrooms (with two toilets) with two different systems were allocated for each room and therefore according to the number specified by the Owner (16 persons per room) where a bathroom is allocated for every 8 persons (10 times more than the rates in Mina camps). The first system has two complete bathrooms where the utilization efficiency becomes used for each bathroom at the same time ( 2 users.), and the second system is two bathrooms divided into two spaces, one containing 2 toilets and the other contains 2 showers so that the utilization efficiency becomes higher and is 4 users at the same time. - The system of two bathrooms internally divided showed negatives, including: limited space, difficulty of movement, the absence of external doors and water leakage to the rooms from the showers, so the proportion of $64 \%$ of pilgrims preferred the system of the two complete bathrooms. $61 \%$ of the pilgrims said that the waiting period to enter the toilets is appropriate and those who had previously performed Hajj in Mina camps reported that the toilets showed a very big qualitative leap from their counterparts in the camps.

- The mediation of the entrance of the room showed a movement conflict with the entry of the two bathrooms and caused inconvenience of the lighting and noise to the sleepers in the room.

\subsubsection{Elements of Horizontal and Vertical circulation:}

\section{A. Elevators:}

Elevators are the most important elements and the most influential on the use of buildings, especially with the height of 13 floors and the multiple fixed peak times throughout the day, and therefore had a greater role in the emergence of the biggest negatives and problems related to all elements of the buildings.

- This is reflected on the evaluation by all parties, which was represented in: - The elevators number is limited and the lack of their capacity - Small area of the elevator hall - Congestion and accumulation in all floors (Figure 14.1) - Waiting for long periods of time - Using elevators in the transport of services, supplies and waste for lack of service elevator and landfill (Waste tube) - Lack of private lifts for men and women.

- $54 \%$ of pilgrims (Hajj 29) reported that there is no fluidity and flexibility in movement during normal times and their percentage increases to $82 \%$ during peak times. $97 \%$ indicated that they suffered from congestion and waited at least in some of the times, and the waiting time exceeds 15 minutes at peak times and from 5 to 10 minutes in normal times. $80 \%$ of them 
used escape stairs at different times to avoid crowding. Pilgrims' determination rates for congestion at all times of peak movement (from 10\% at the time of the return from the rituals to $16 \%$ during lunch) were very close, and the lowest congestion and waiting percentage was in the second floor (19\%) and the highest was in the typical floor that amounted (31\%).

- $73 \%$ of pilgrims (Hajj 30) made observations on the elevators in terms of number and capacity as a main problem.55\% of them said that they waited for elevators from 5 minutes to more than 10 minutes, $35 \%$ of them think that the waiting time is very long, and $38 \%$ think it is medium, and $60 \%$ said that the elevators are not enough.

\section{B. Stairs:}

- $78 \%$ (Hajj 29) and 82\% (Hajj 30) of pilgrims indicated the clarity and appropriateness of the staircase location; $81 \%$ (Hajj 29) and $72.8 \%$ (Hajj 30) of pilgrims reported that the staircase had sufficient capacity.

- $80 \%$ of pilgrims (Hajj 29) and 50\% (Hajj 30) of the pilgrims reported that they used the escape stairs taking into account that $48 \%$ (Hajj 29) and 44\% (Hajj 30) were praying in the rooms, corridors or outside the building. Approximately 45\% (Hajj 29) and 23\% (Hajj 30) did not eat at the restaurant to avoid waiting for elevators and the difficulty of using stairs.

- The most important negative observations on the staircase: The main stair is not connected to the two escape stairs in the first and second floors except through the functional spaces - the escape staircases are not connected to the main entrance on the ground floor because of the small or canceled dining hall space and the absence of places for pilgrims to sit, storage areas, a landfill and places for workers accommodation. The stairs were used for sitting by the workers and pilgrims to eat (Figure 14.2), smoking cigarettes, spreading clothes on the fence of the stairs, storing some supplies and put garbage bags, all of which negatively affect the achievement of safety and security requirements.

\section{Horizontal circulation corridors in residential floors:}

- Horizontal movement corridors are sufficient in capacity and suitable in relation to the rooms according to $80 \%$ of pilgrims, but depending on the circumstances of each building and differently, the corridors were occupied with some fittings, supplies and drink preparation machines, and in the buildings where the restaurant was canceled, the corridors were occupied by sitting or in making buffets to serve food (Figure 14.3,4), which posed a risk to the safety and security in emergencies and caused inconvenience in the movement as reported by $81 \%$ of pilgrims. The occupation of spaces in front of the doors with pilgrims' shoes also emerged as a negative element.

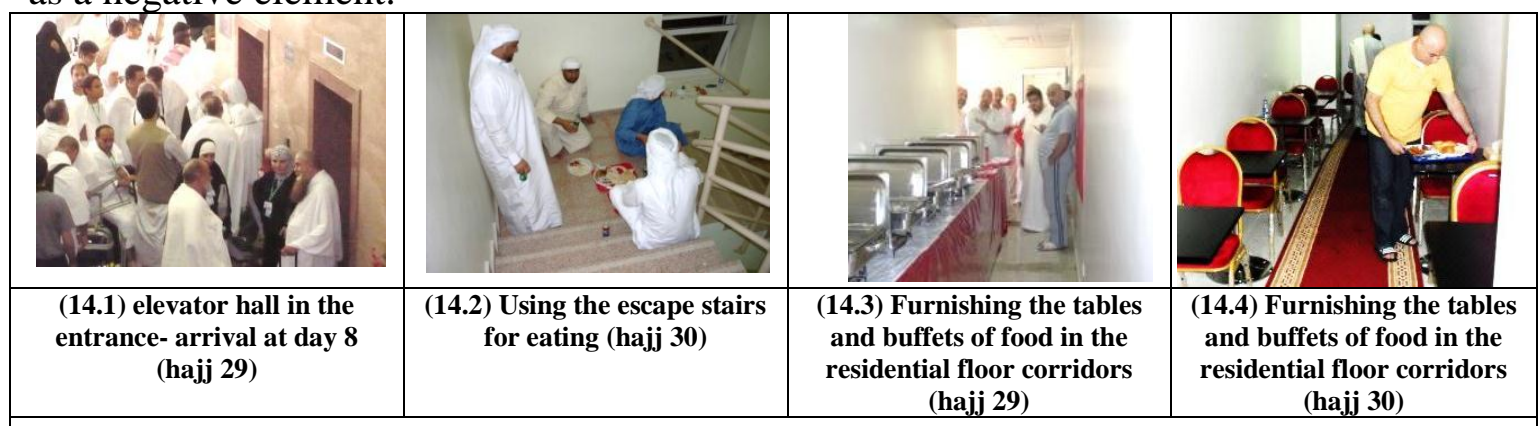

Figure (14): Occupying and using the movement elements throughout the pilgrimage days (The researcher, hajj 29 - The Custodian of the Two ..... , hajj 30)

\subsubsection{Service rooms, technical fittings and finishes:}

- The majority reported that there are no services that are required to be provided in the building or the site (health center - barber - ATM - telephone booths - buffets in floorscafeterias - gift shop - places for worker accommodation - toilets in the ground floor) as well as the insufficient public toilets attached to the prayer area and common with the restaurant, while everyone praised the technical fittings and finishes.

\subsection{Subjects of Evaluation:}

7.4.1 The evaluation of the pilgrimage experience through the accommodation in the buildings in Mina (hajj 30) and comparing with the camps (hajj 29): 
- $32 \%$ of pilgrims reported that the pilgrimage experience through accommodation in the buildings is excellent, $28 \%$ very good and $24 \%$ good.

-The evaluation of the housing of the buildings in Mina compared with the camps (hajj 29):

A. For those who performed pilgrimage in camps before: $70 \%$ said the buildings are much better and $23 \%$ said they are better.

B. For those who never performed pilgrimage in camps before: $68 \%$ said they are much better and $20 \%$ said they are better.

7.4.2 The order of the pilgrimage days in respect of the problem severity and rate (hajj 29) as per the pilgrims' evaluation:

- Most of the pilgrims (49\%) said that the 8th day of Dhul-Hijjah (Arrival at Mina) was the most problematic day. The order of the problems of that day in terms of severity was as follows: Overcrowding and congestion outside the building (26\%) - Waiting to get off the buses upon arrival due to slow traffic and congestion (24\%) - Congestion of motorways $(21 \%)$ - Congestion of the pedestrian roads $(19 \%) \ldots .$.

- The rest of the days are close in terms of problems severity and rates ranging from 8 to $16 \%$ (Figure 15.1).

7.4.3 The order of the problems according to the severity of each during the days of pilgrimage (hajj 29) according to the evaluation of the pilgrims:

Over- crowdedness of motorways $(28 \%)$ - Overcrowding and congestion outside the building $(21 \%)$ - Waiting to get off or get into the buses (17\%) -walking up of the (steep) sloped road from the site entrance in the way back from throwing pebbles (19\%)-Congestion of the pedestrian roads (15\%). (Figure 15.2)

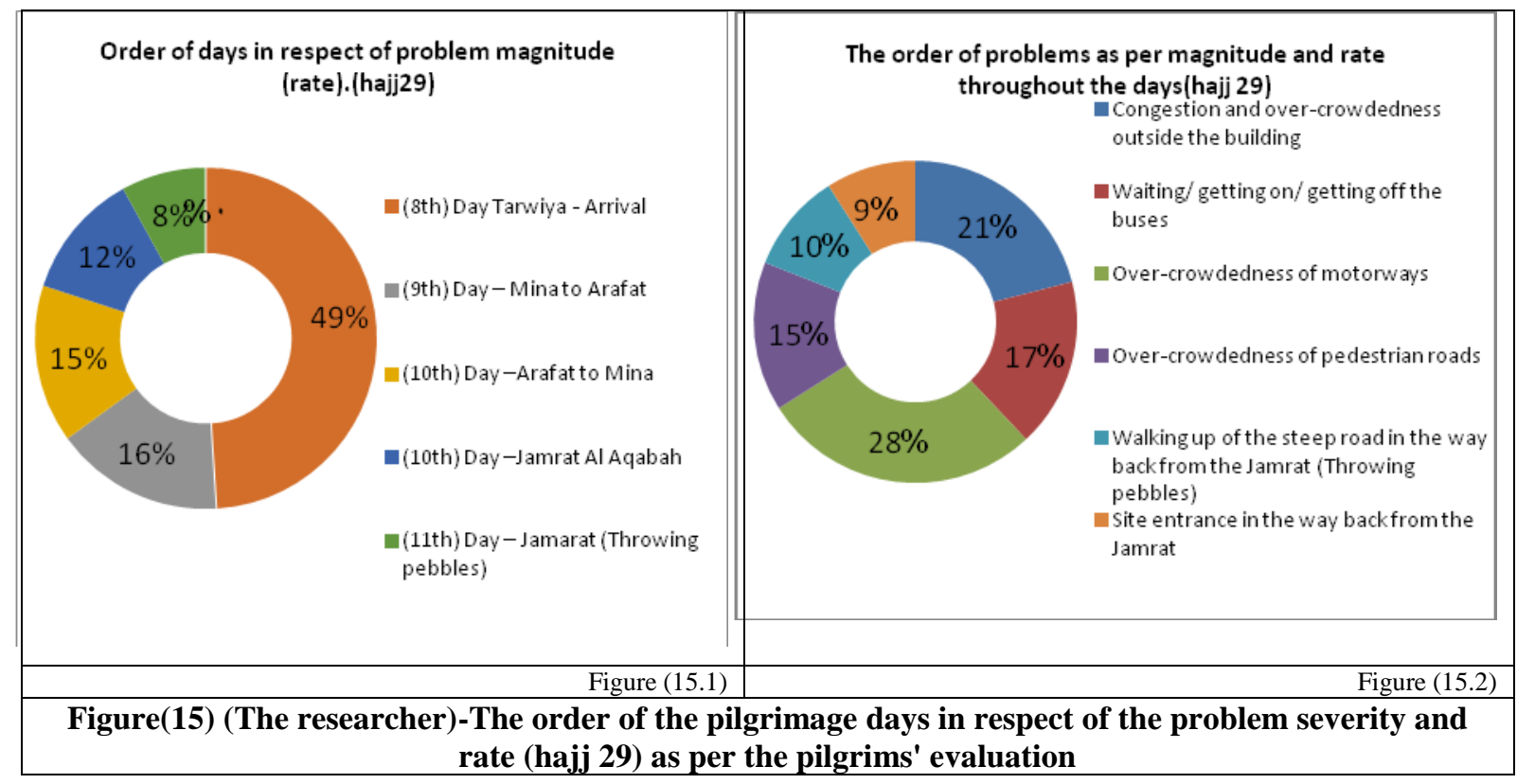

7.4.4 The most suitable for expansion of construction on the mountains ( buildings or tents ) (hajj 30):

- $88.2 \%$ of pilgrims and $66.6 \%$ of the Motawifs said that buildings are more suitable for expansion on the slopes of the mountains (Figure 16.2).

- Buildings came in the first place to the pilgrims preference for the general form of Mina (Considering the general character ) by $(58.3 \%)$, followed by the preference that Mina becomes a mixture of buildings and tents by $30 \%$, and tents by $8.6 \%$, and the reasons that pilgrims preferred buildings were: Security - availability of services and finishes - hardship easing. The preference of those who chose a mixture of buildings and tents was to satisfy the desires of the people and achieve the absorptive increase, while the Motawifs and operators 
preferred that Mina holds a mixture of buildings and tents by $60 \%$, then $20 \%$ preferred buildings only, and finally followed by $13.3 \%$ preferring tents only (Figure 16.3).

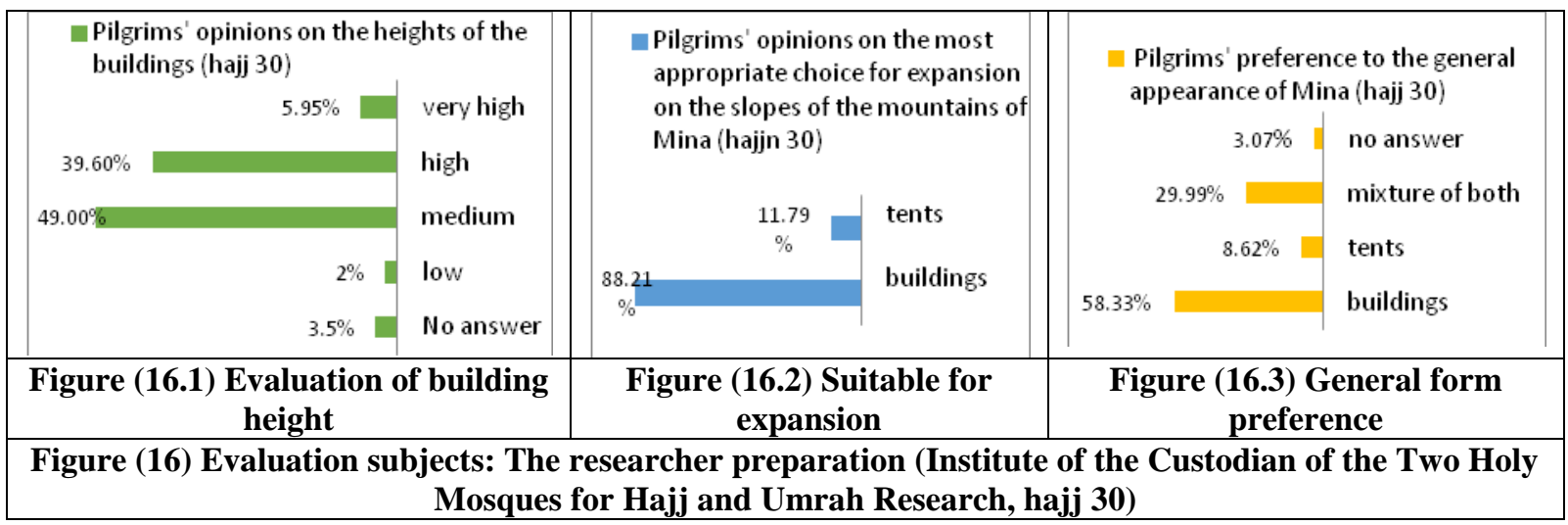

7.4.5 Buildings suitability with the needs of pilgrims (hajj 29 -30):

- All the Motawifs and officials stated that the buildings are proportionate with the behavior of pilgrims taking into account the negative observations of each of the elements of evaluation that affect the amount of this proportion.

8. Summary of evaluation and the proposals of the parties to the evaluation (pilgrims and motawifs) of the evaluation elements and subiects (haii 29 -30):

o Proposals are subdivided into scalable proposals that can be developed in existing buildings and that applied in future projects, and proposals to be considered and applied in future projects:

8.1 Evaluation element proposals:

8.1.1 Site (Layout), transportation, movement and outer spaces:

To increase the waiting areas for buses and increase the places of picking up and dropping off of pilgrims in front of the buildings and to separate the movement of services and cars from the movement of pilgrims- To provide effective transportation means from Mina to Arafat and Makkah- To provide services at the site level- To provide special places for praver that do not interfere with the movement of pilgrims and services- To provide effective means of transportation from the entrance of the site to the buildings (Escalators or travelators and to shade the outer spaces and achieve visual contact with Mina.

\subsubsection{Buildings:}

8.1.2.1 Entrance, reception and elevator hall:

- Increase the area through the inclusion of external spaces down the building in the ground floor - Increase the seating areas - Provide toilets and buffets (cafeterias) - Provide entrance to services.

8.1.2.2 Functional spaces ( public elements ), and services:

- To provide places that for seating activities, prayer halls and dining halls (according to the original design), and increase the low areas to accommodate the absorptive capacity (on account of the rooms and the reduction of the absorptive capacity (The researcher)).

- To allocate one or more separate floors for each activity pursuant to the acceptable rates, with adequate services for each of them (toilets, ablution areas, office, cafeteria....) and to achieve privacy among women and men.

- To address the problem of elevators, including the distribution of each activity on an upper and a lower floor or distribute it on each floor or each two or three floors to facilitate the movement capacity through the stairs to one or two floors up or down (on the account of rooms and the reduction of the absorptive capacity and this requires the distribution of eating spaces and service areas connected with the kitchen elevator on the floors ( The researcher) ) To provide the mentioned services in the building. - To provide an effective means for the disposal of waste. 
- To increase kitchen area and operational capacity - To provide services outside the buildings in the( layout ) site (mosque - restaurant complex - seating areas - prayer areas .....) while regarding the solution of the problem of elevators.

\subsubsection{Residential Rooms:}

- To diversify the sizes of rooms and thus the number of individuals - Address the openings issue to achieve privacy - Address the problem of the interference between the entry of the room and the entry of the bathrooms and the related inconvenience of lighting and noise.

- To control air conditioning from inside the residential rooms - Reduce the number of pilgrims in the rooms to 12 pilgrims.

\subsubsection{Elements of horizontal and vertical circulation:}

* Elevators: To distribute public spaces (activities) on the floors (item 8.1.2.2) - regulate operational aspects -To set elevators for men and others for women -To add elevators at the end of the corridors (one for service) - To add an elevator in the escape stairs space (not acceptable with the requirements of security and safety (The researcher) -To add a landfill to minimize the elevators usage (for type B) - To increase the number and capacity of elevators and elevator hall area.

* Staircase and Corridors: To extend the main stair in the whole building, which can also be converted to an electric stair (escalator) - allow the main stair to connect to the escape stairs in the first and second floors without going through the activity spaces - allocate spaces to contain negative activities for the use of stairs and corridors (on account of the rooms) cancel the glass doors separated for corridors and elevator halls in floors.

8.2 Summary of the (consistent)visualizations of all parties to the subjects of evaluation: o The pilgrimage experience through buildings is satisfactory and better than pilgrimage in the camps (despite the observations and negatives).

$\circ$ The most problematic day is the $8^{\text {th }}$ of Dhul-Hijjah. Most problems over the days are related to congestion, overcrowding, slow movement of roads outside and inside the site and in front of buildings, as well as the difficulty of walking up of the (steep) sloped road leading to the buildings.

- The pilgrims' preference for buildings as a general form for Mina is followed by a mixture of buildings and tents, which is preferred by the Motawifs.

$\circ$ Most pilgrims and Motawifs believe that the buildings are more suitable for the expansion on the mountains. Motawifs believe that the buildings are commensurate with the needs of pilgrims (taking into account the treatment of the negative sides), and the majority pointed out that the heights of the buildings are medium.

\section{DISCUSSION - RESULTS:}

- Pilgrimage experience through the housing buildings of pilgrims in Mina area has achieved a satisfactory level of success and an acceptance of pilgrims and all the parties, despite the observations and proposals concerning a number of shortcomings and negatives at the level of the site and buildings.

- Buildings are an effective solution to expand on the slopes of the mountains of Mina area in terms of: - The general shape of Mina with regard to the element of tents - absorptive capacity - suitability for the behaviors and needs of pilgrims - high level of safety and comfort.

- Compared to the camps, the buildings provided many fundamental advantages and differences in terms of the following: The share of one person in a room area of two bathrooms (more than twice the camps), which is a paradigm shift - share of one person in the toilets 10 times more than camps where toilets are grouped in outdoor spaces - safe indoor circulation elements (in the camps, circulation elements are outdoor and open) - service and functional spaces and its rates (which are not available in the camps and practiced in the accommodation space(sleeping places) allocated to the individual) - the level of safety and comfort that is associated with the finishing, air conditioning, safety requirements, protection from weather factors and the prevention of noise and pollution that is associated with the road level in camps.

- Compared to the hotels of Makkah and Madinah: Despite the high capacity, buildings did not provide spaces and equivalent rates in terms of: - The area per person in the rooms is nearly a quarter and in the bathrooms of the room is nearly the half (but this rate is only 
acceptable for rooms without the rest of the building elements because of the limitation conditions of the pilgrimage period and the need to increase the capacity) - The share of one person in services, elevators and functional spaces (public activities) is less than a quarter (or not available or canceled to increase the number of rooms and increase the capacity), but the provision of these elements at appropriate and considered rates is a prerequisite for the Generalization, activation and success of the pilgrimage mechanisms in buildings.

- The design did not take into account the difference in management, operation, mechanisms, requirements and service of the pilgrims' accommodation vertically in the buildings from horizontally in the camps in Mina, or the difference in terms of the operational process and rates and the distribution of building elements from hotels in general, and in Makkah and Madinah in particular. However, balance was not achieved between the increasing of the capacity and its requirements at the level of the site and buildings, which was reflected on the negative observations of pilgrims. At the level of the site and outdoor spaces, the negatives appeared in the poor capacity of roads and bus stops( dropping off and picking up); the difficulty of separating pedestrian traffic from the motorized traffic and its overlap with the activities of prayer, seminars, food sessions and service movement due to lack of functional elements and services on site and in the buildings; and the lack of adequate and effective means of transportation at the level of camps (valley) and with the areas of Makkah and the central region. Regarding buildings, the disadvantages were represented in insufficient of functional elements ( activities spaces) area and low share per capita, unavailability or cancellation some of them as well as services, inadequate its location in the building and relations between them (according to the traditional hotel design) which was a burden on the elevators and elevator halls and led to the inappropriate use of stairs and corridors. - the limited number and capacity of elevators and the assembly of their doors in a single space is considered the main problem of the buildings that are based on heavy vertical movement - the inadequacy of the room entrance and its relationship to the bathrooms.

\section{Recommendations - Planning and design directives: First: Directives in general and at the level of the site}

$\circ$ Generalizing the expansion on the slopes of the mountains within the legal boundaries of Mina area (especially the northern region, which includes areas with favorable tendencies for development and construction) through pilgrims housing buildings according to appropriate rates, densities and absorptive capacity as an optimal solution to accommodate the current and targeted numbers of pilgrims in the future in proportion to the absorption capacity of the rest elements of the pilgrimage (hajj) system.

$\circ$ Diversifying the means of transportation with the Haram of Makkah, the central area and the different regions of Makkah at the level of Mina in general and at the level of expansion and extension on the slopes of the mountains in particular. (Tunnels through the mountains that link the main levels of the extension of the buildings with areas outside Mina area - the adoption of a road network (tunnels) and areas for buses of pilgrims ( bus stops - areas of drop off and pick up - service areas) down the valley of Mina area to serve the camps and the levels of buildings through cores (platforms) for vertical circulation elements (stairs, elevators, escalators) (Figure 18) - Train - roads and bridges - cable car (Chairlifts) - ....). Providing a percentage of buildings with airstrips for ambulance and emergency planes.

$\circ$ Achieving vertical separation between the pedestrian traffic and motorized traffic through the pedestrian level-s (bridge-s) linked to the entrances to the buildings At the first floor level - linking the levels of buildings with the dropping off and picking up areas allocated to the buses of the pilgrims of the buildings that permeate the camps adjacent to the foot of the mountain by the level of the valley through cores of the vertical circulation elements (and compensating the omitted tents using (terraced) tiered multi- floor tents, which were presented as one of the acceptable alternatives to expand on the slopes of the mountains). This is made to reduce the number of buses required to rise to the level of buildings and reduce the hardship on pilgrims back and forth to perform the rituals(Figure 17, 18, 20);- to provide shaded areas and paths for pedestrians and use travelators (moving walkway)to encourage the movement of pedestrians; - achieve a gradation for urban spaces in the extension areas and provide sufficient services that are not accommodated by buildings; and to increase street width between buildings. 
- Taking into account the visual integration and architectural character among the buildings and the characteristics of the environment of Mina (tents, mountains, gradation) and reducing the sense of buildings as an intruder (confirming horizontal direction through tiered buildings( setback of buildings floors ) and connection of some extended floors between buildings), diversity of building heights and in tiered floors and connected floors(Figures 17, 18).

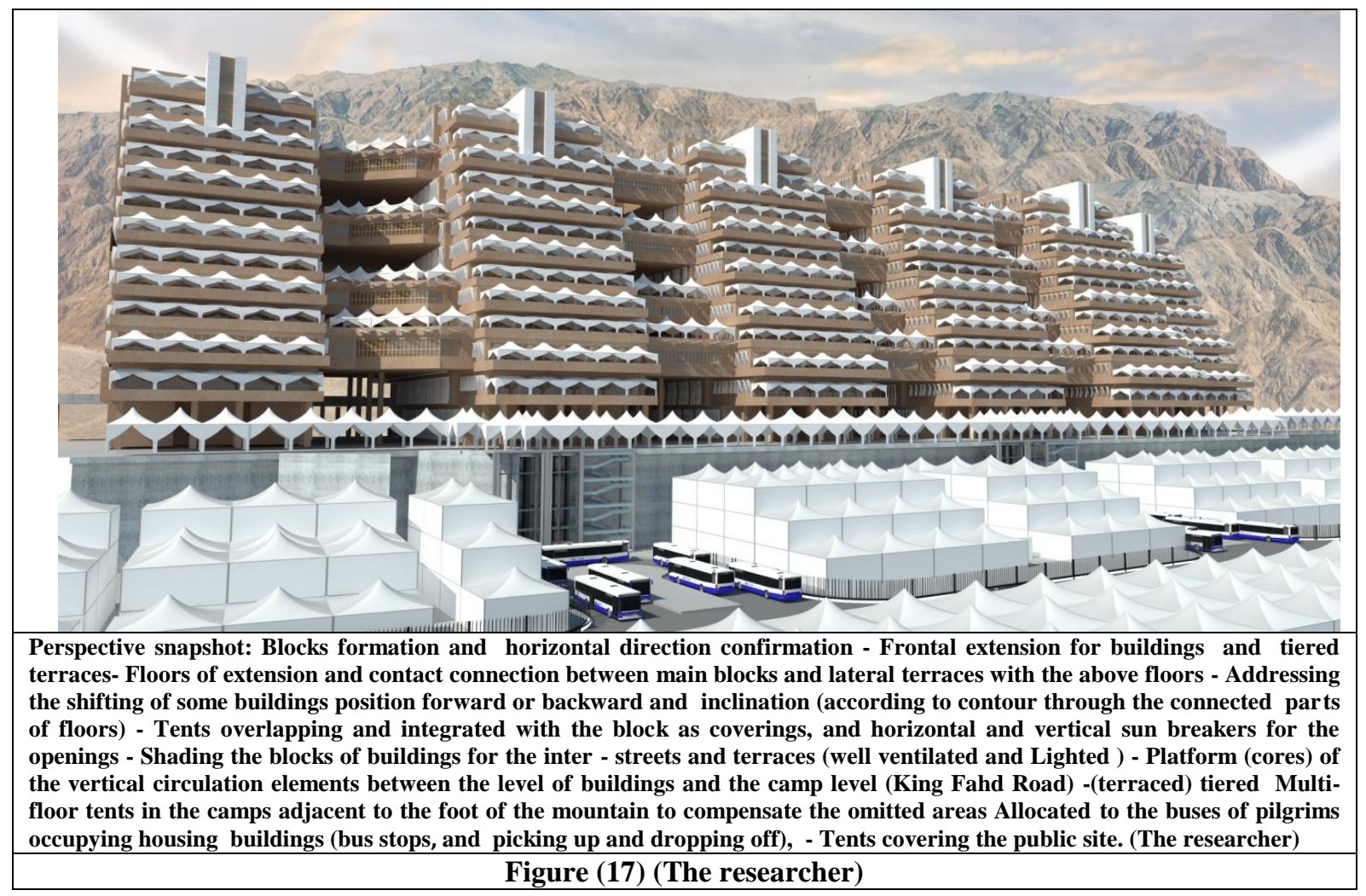

- Achieving sustainability standards at the level of construction and buildings (electric power, solar energy, building materials and processors...) - Providing the requirements of security and safety (evacuation, weather factors, avalanches ...).

- Taking into account the cost in construction, maintenance and operation and maximizing the investment return through the operation of buildings throughout the year for (Umrah) to contribute to meet the growing demand for pilgrims housing of Umrah and hajj at the level of Makkah and to support that through attractive activities.

Second: Design directives at the level of the building:

- Increasing the floor area ratio (FAR ) (total floors' area to the lot area (equal to coverage area) ) without increasing the height of the buildings through the extension and the connection of some of the upper floors between the buildings (above the streets between buildings, the main road and the front area overlooking Mina) for each of the several adjacent buildings according to visual and urban studies and contour in addition to the inclusion of the open spaces down the building on the ground floor in order to: - Provide the necessary space to increase the areas and spaces ratios of public activities and services and increase the share of one person to appropriate rates (to compensate for the lack of or deficit in those activities at the level of buildings and site) - Increase the number of rooms in the building - Reduce the number of individuals in the room (from 16 to 12 individuals per room) without reducing the number of individuals per unit area of the lot area (or achieving an increase by comparing equal occupancy rates for rooms among the proposed development of buildings and the existing buildings).

O Increasing the possibility and distribution of an organized entry and exit from the building from different directions according to different times and purposes - Expansion of the entrance, reception and elevator hall to allow additional main entrance through changing the location of the main stair. 
- Solving the problem of the deficit in the number of elevators and the overcrowding and congestion in elevator halls according to an equation that includes: (1) - Increasing the number of elevators - Distributing the spaces of public activities to a number of residential floors, each of which serves the floors that precede and follow (to reduce the use of elevators). (2) - Distributing elevators on the floors based on the distribution of public activities spaces on the floors and the relation among floors. (3) - Distributing of the opening of elevator doors in all floors on more than one direction. (4) - Allocating and distributing of elevators for men and other elevators for women. Adjusting the position and conversion of the main stair to an escalator that serves the first three floors and can be extended to the entire floors of the building according to a study (at the expense of a number of rooms).

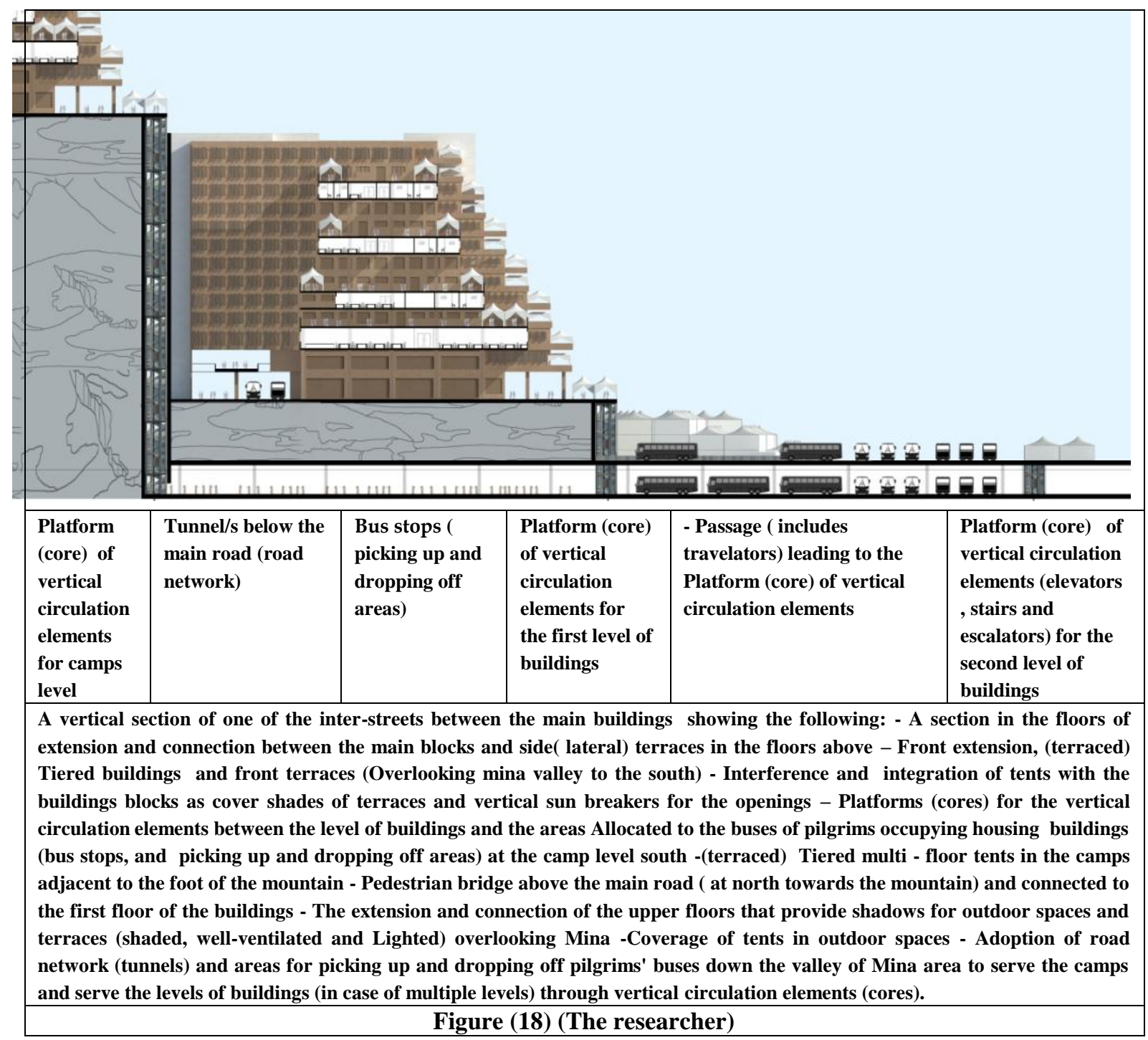

○ Distributing the spaces of public activities, rooms, services and elevators allocated for women on one side in all floors and similarly to men on the other side to maintain privacy and smoothness and preventing the movement interruption vertically and horizontally.

- Providing terraces in buildings to compensate for the shortage of outdoor spaces without prejudice to the capacity of the site and achieving visual contact with Mina area by employing (terraced) tiered floors and connected floors between proposed buildings blocks. (Figure 17, 18)

- Providing two entrances for the service and the kitchen, each has an elevator serving all the floors of the building through a floor service room and a kitchen service room in each floor. 
- Providing a percentage of rooms with larger areas for the numbers from 16 to 24 persons with adequate number of bathrooms, and a smaller rooms for the V.I.P.

o Redesigning the room entrance and the two bathrooms to avoid the problems of movement and the inconvenience of lighting and noise and the accumulation of shoes by moving the entrance and the entrance lobby to become a side distribution space separating the sleeping space and the entrance of the bathrooms and the outer corridor - adoption of a system of two complete bathrooms (and three for larger rooms) - Controlling air conditioning from inside the room (Figures 20,21).

- Adopting fixed furnishing systems for the building spaces according to criteria that allow the building to continue operating throughout the year, including the use of beds, which requires reducing the number of individuals in the room or the use of two-tier beds to allow space for movement as well as the provision of cupboards, shelves and .......

- In the case of adopting the activation of the use of future buildings developed throughout the year to serve the Umrah, it may require the study of the possibility of increasing some elements and increasing service elevators and floor service rooms, and taking into account the impact on outdoor spaces and public services and the provision of attractive elements.

- A number of directives (proposals) can be applied to existing buildings, at least in part of, but require high-cost construction and execution solutions and treatments. It can also be applied to different design alternatives.

- Applying the recommendations (directives) on a developed design, calculating their rates and comparing it with the original design in preparation for the execution through a future project and to be evaluated through (P.O.E).

Illustrative summary of applying the recommendations, guidelines and associated achieved rates: (Figures $17-21$ )

- Data, rates and average increase in the proposed development (design directives) compared to the pilot project for similar occupancy rates (16-12 individuals per room), and the increase rates in the proposed development (12 individuals / room) compared to the pilot project (16 individuals / room): includes comparison with (A3, the original and executed design)).

(A) By comparing similar occupancy rates (16 and 12 persons per room) with the pilot project (model A3, the original design), the proposed development (design directives) achieved the following increase ratios: Number of persons in the building $135 \%$ compared to (A3) and $125 \%$ to $(\mathrm{A} 4,5)$.

Increasing the( F.A.R ) $(164 \%)+(20 \%)$ terraces, and total floors area to the site area of the building (152\%). Increasing the area ratio of the floors of public activities (spaces) in addition to the public activities in the residential floors, to the total building floors area (159\%). Increasing in areas: The site area of the building (building land, sidewalks, and intra-streets ) (116\%) - Total area of the ground floor (107\%) (to closed area 353\%) - Total area of the building's floors $(176 \%)+$ terraces $(21.8 \%)$ ( provide areas for seating, prayer, seminars and eating) - Restaurant area (474\%) - Kitchen (296\%) - Prayer hall (297\%) Seating halls (187\%) - Administration (194\%) - Adding halls for seminars $\left(462 \mathrm{~m}^{2}\right)$. Percentages of increase in the numbers of the following: rooms (139\%) - elevators( $300 \% 0$ - public toilets (200\%). ( the percentage previous rates are identical in the comparison of item (B) ).

Percentages of increase in the rates of person's shares in the building's elements compared to (A3): The land area of the building (80\%) - The site area of the building (87\%) - Total building's floors area.(132\%) + terraces $(15 \%)$ - Residential room area $(110 \%)$ Room's bathrooms $(133 \%)$ - restaurant area $(367 \%)$ - kitchen area $(222 \%)$ - Prayer halls $(225 \%)$ - Seating Halls' area (salons) (141\%) - Administration (146\%) - adding 3 halls for seminars $\left(0.136 \mathrm{~m}^{2} /\right.$ person $)$ - Elevators rate to the number of persons $(224 \%)$ - Share of one person in public toilets $(150 \%)$.

(B) Compared to the original design (A3) (16 individuals / room), the proposed development (12 persons / room) achieved increased rates as follows (Table 4): In the number of persons in the building (101.7\%), (In case the proposed development is occupied 
by 16 persons per room, the increase rate is 135\%). Percentage of increase in the rates of person's shares in the building elements: The land area of the building (104.5\%)- The site area of the building $(114 \%)$ - total building's floors area $(173 \%)$ and terraces $(21 \%)$ Residential room area $145 \%$ - Room's bathrooms 133\% - Restaurant area $482 \%$ - kitchen area $(291 \%)$ - Prayer halls ( $298 \%)$ - Seating Halls' area (salons) (183\%) - Administration $(194 \%)$ - Adding 3 halls for seminars $\left(1.77 \mathrm{~m}^{2}\right) /$ person - Elevator rate to the number of persons $(295 \%)$ - Share of one person in public toilets (197\%) .

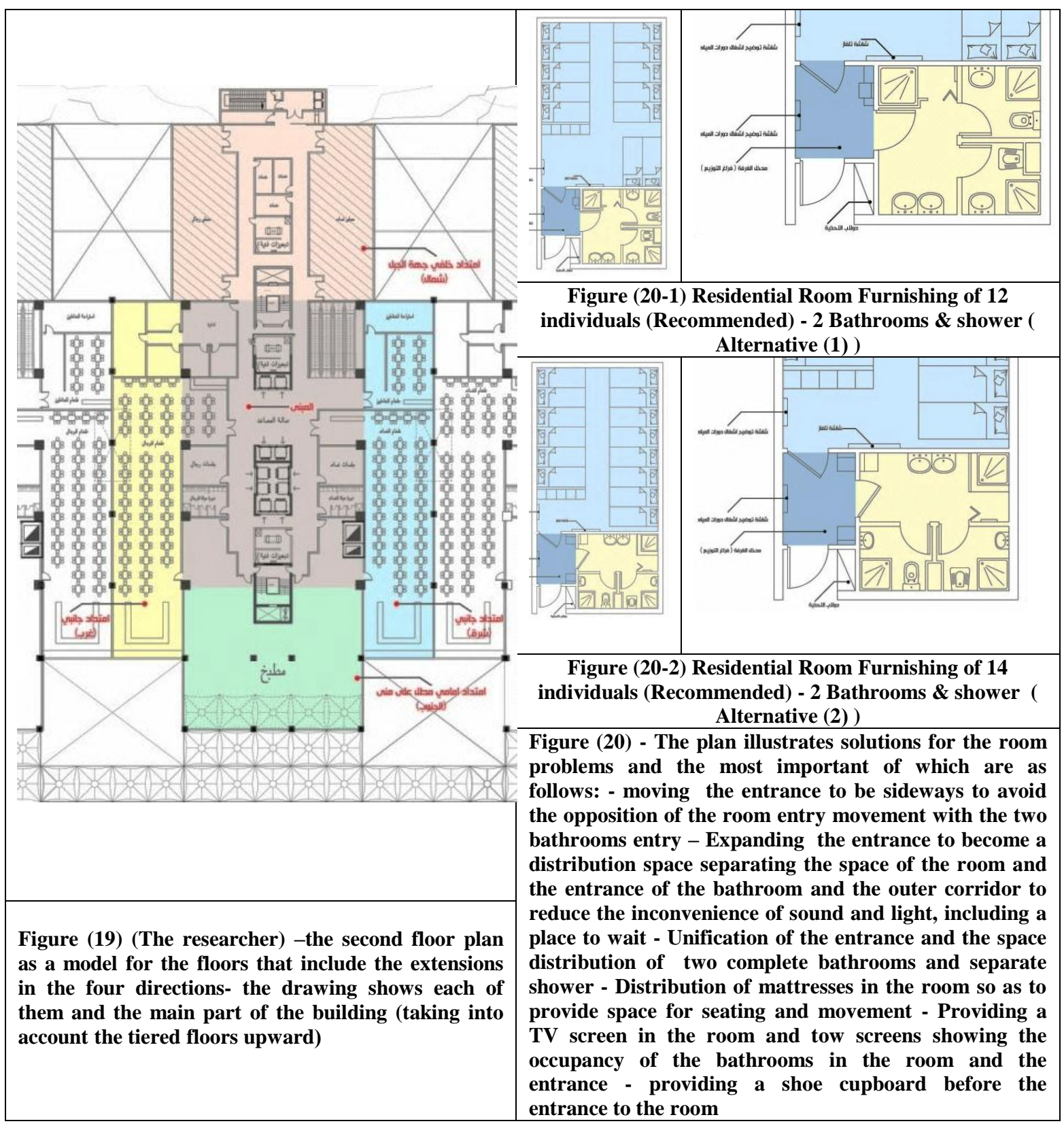




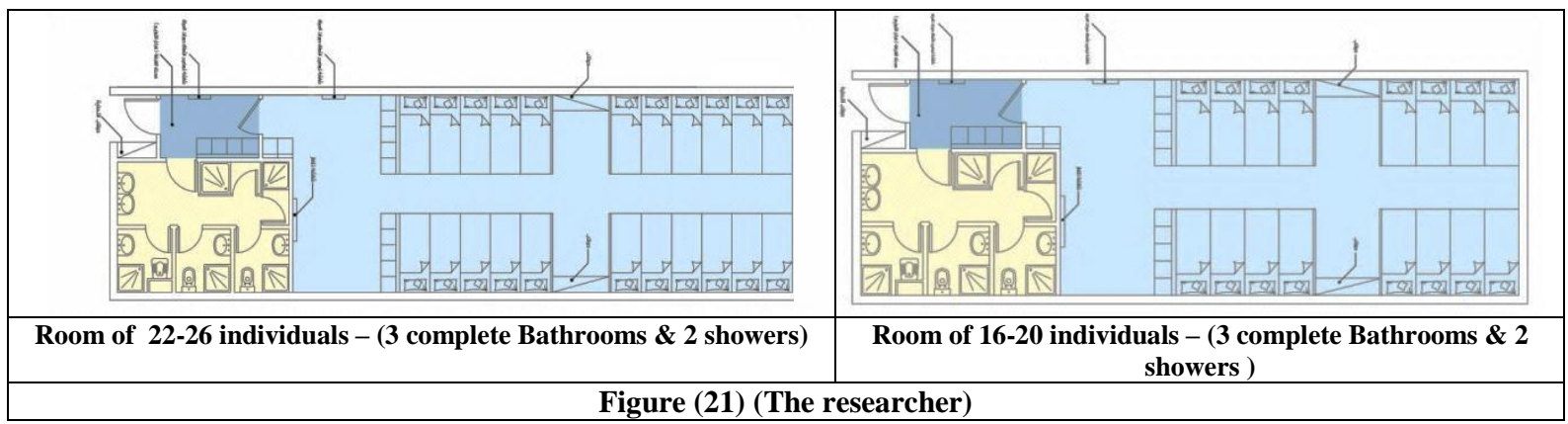

\section{REFERENCES:}

1. Ahmed M .Shehata and Amr M . El-Zawahry, (2016), "Post Occupancy Evaluation of Pilgrim's Accommodation: A Case Study of Mina in Makkah", WIT transactions on Ecology and the Environment, Sustainable City, WIT press, London, U.K., Volume 204, 2016.

2. Bordas, B .andLeaman, A. (eds.) (2001).Assessing building performance in use. Building Research \& Informatio, 29 (2)

3. Duffy, F. (2008).Building appraisal: A personal view. Journal of Building Appraisal 4 (3): $149-156$.

4. Preiser, W . F. E., Rabinowitz, H. Z. and White, E. T. ( 2015 - 1988).Post Occupancy Evaluation. New York: Van NostrandReinhold Company.

5. Preiser, W . F.E. and Vischer, J. C. (eds.) (2004).Assessing Building Performance: Methods and Case Studies. Oxford, UK: Elsevier.

6. Preiser, W. F. E. (1995).Post occupancy evaluation: How to make buildings work better. Journal of Facilities 13 (11):19-28.

7. Preiser, W. F. E. (2002).The Evolution of Post Occupancy Evaluation: Towards Building Performance and Design Evaluation, Chapter 2. Washington: Federal Facilities Council, National Academy Press, pp. 9-22 .

8. Preiser, W. F. E., Rabinowitz, H. Z. and White, E. T. (1988).Post Occupancy Evaluation. New York: Van Nostr and Reinhold Company.

9. Queensland Department of Housing and Public Works (QDHPW), (2013).Strategic Asset Management Framework Post Occupancy Evaluation, Post Occupancy Evaluation, In Best Practice Guidelines December, The State of Queensland.

10. Watson, C. (2003).Review of building quality using post occupancy evaluation. Journal of Programmed Education Building ,35: 1 - 5

11. Voordt van der, D. J. M. and Wegen van, H. B. R. (2005).Architecture in Use: An Introduction to the Programming, Design and Evaluation of Buildings. Oxford: Elsevier.

12. Vischer, J. (2002).Post Occupancy Evaluation: A Multifaceted Tool for Building Improvement, Chapter 3. United States :Federal Facilities Council, The National Academy Press , pp. $23-34$

13. Makkah Urban Observatory, "Report of the Urban Indicators of Pilgrimage Results", Holy Makkah Municipality, Second Session of Pilgrimage Season of 1432 AH.

14. The Custodian of the Two Holy Mosques Institute for Hajj and Umrah Research (Umm Al-Qura University) \& Central Administration of Development Projects, Ministry of Municipal and Rural Affairs, (Abdullah. M. Fouda, Amr. M. Z. Elzawahry, Ahmed. K. Afifi), Evaluation Study of the Pilot Project of Housing on the Slopes of Mina (Pilgrimage Season of $1430 \mathrm{AH}$ ) - Final Report to submitted the Municipality of the Development Authority of Makkah, Madinah and Holy Areas, 2010 AD.

15. Saudi Commission for Tourism and Antiquities, criteria for the classification of hotels in Makkah and Madinah, $1433 \mathrm{AH}$. 
16. Saudi Commission for Tourism and Antiquities, Licensing Department, List of Requirements for Classification of Hotels (Makkah and Madinah), $1437 \mathrm{AH}$.

17. Central Hajj Committee- Guiding Committee, "the comprehensive plan for the Holy Areas, the report of the primary and final plan", 1419 AH.

18. Amr Mohamed Zin Eldin ElZawahry, Development Units related to group and Place with a Special Reference to Greater Cairo, PhD Thesis, Faculty of Engineering, Cairo University, 2000 AD.

19. Amr Mohamed Zin Eldin El Zawahry and Ahmed Abdel-Rahman Shehata, "Improving the Visual Characteristics of the Urban Environment in Mina Area", Journal of Engineering Research in Port Said, Faculty of Engineering, Port Said, Suez Canal University, Volume 13, Issue 1, March 2008 AD.

20. Mina Real Estate Co.( General Organization for Social Insurance - Public Pension Agency ), ( 2007). (MREC) 